\title{
Crisis Governance in the Administrative State: 9/11 and the Financial Meltdown of 2008
}

\section{Citation}

Adrian Vermeule \& Eric A. Posner, Crisis Governance in the Administrative State: 9/11 and the Financial Meltdown of 2008, 76 U. Chi. L. Rev. 1613 (2010).

\section{Published Version}

http://www.law.uchicago.edu/files/files/248-442.pdf

\section{Permanent link}

http://nrs.harvard.edu/urn-3:HUL.InstRepos:10875738

\section{Terms of Use}

This article was downloaded from Harvard University's DASH repository, and is made available under the terms and conditions applicable to Open Access Policy Articles, as set forth at http:// nrs.harvard.edu/urn-3:HUL.InstRepos:dash.current.terms-of-use\#OAP

\section{Share Your Story}

The Harvard community has made this article openly available.

Please share how this access benefits you. Submit a story.

Accessibility 


\title{
UNIVERSITY OF CHICAGO LAW SCHOOL \\ John M. Olin LaW \& Economics Working PAPER No. 440
}

(2D SERIES)

\author{
UNIVERSITY OF CHICAGO LAW SCHOOL \\ Public LaW ANd Legal Theory Working Paper No. 244
}

\section{Harvard Law School: Public LaW \& Legal Theory Paper Series Harvard Public law Working Paper Number 08-50}

CRISIS GOVERNANCE IN THE ADMINISTRATIVE STATE:

9/11 AND THE FINANCIAL MELTDOWN OF 2008

\author{
Eric A. Posner and Adrian Vermeule
}


Crisis Governance in the Administrative State:

9/11 and the Financial Meltdown of 2008

\section{Eric A. Posner ${ }^{*}$ and Adrian Vermeule ${ }^{* *}$}

On September 11, 2001, a massive terrorist attack on the World Trade Center in New York killed over 3,000 Americans. The markets plunged, and airline firms reeled towards bankruptcy. Executive action and legislation followed, both to stabilize the markets and to counter terrorism. One result was seven years of debate about inherent executive power, the nature and quality of emergency lawmaking by Congress, and the risks, benefits and harms of government action.

On September 18, 2008, after months of economic anxiety and several massive bailouts of distressed firms by the government, the stock market had its largest single-day drop since Sept. 11, 2001. Officials and commentators declared an economic emergency and moved on two fronts. The Treasury and Federal Reserve dusted off a 1932 statute and invoked the Fed's authority to stabilize failing firms by lending them money, although some were allowed to fail. Nearly simultaneously, Treasury proposed emergency legislation granting the Secretary some $\$ 700$ billion in spending authority to buy mortgage-related assets, with open-ended administrative discretion. After the plan was initially rejected by the House of Representatives, on September 29, the stock markets fell even more sharply than on September 18. Amid great political controversy and a mounting sense of crisis Congress passed a statute, the Emergency Economic Stabilization Act of $2008^{1}$ (EESA), that not only approved the core of the Treasury's request but granted it additional powers, with qualifications and oversight mechanisms of uncertain force and scope, and with many largely unrelated tax breaks thrown in to sweeten the pill.

Of these two crises, one involved "security," one involved "finance" or "economics." What are the similarities and differences? In positive terms, how did legislators and executive officials behave, and how did the public and elites react? Normatively, what do the two episodes show about the capacities of presidents, bureaucrats, legislators and judges to manage crises in the administrative state, and the rationality of their responses? And what of the legal issues common to both episodes, such as the scope of inherent executive power and the limits of congressional delegation - are the questions the same, and the answers?

\footnotetext{
${ }^{*}$ Kirkland \& Ellis Professor of Law, The University of Chicago.

** John H. Watson Professor of Law, Harvard Law School. Thanks to Elisabeth Theodore for excellent research assistance.

${ }^{1}$ Pub. L. No. 110-343, div. A (2008).
} 
In what follows, we will argue that the two episodes were similar at the first decimal place, but interestingly different at the second, and we will attempt to explain both the similarities and differences. The first claim is that broad political processes and constraints operated similarly in both episodes to create a generally similar pattern of crisis governance and emergency lawmaking. In the modern administrative state, it is practically inevitable that legislators, judges and the public will, indeed must, entrust the executive branch with sweeping power to manage serious crises of this sort. Despite traditional concerns about excessive delegation of power to the executive, who may abuse that power or exploit it for unrelated ends, other actors have no real alternative in such cases. Political conditions and constraints, including demands for swift action by an aroused public, massive uncertainty, and awareness of their own ignorance, leave rational legislators and judges no real choice but to hand the reins to the executive and hope for the best. We will call this the "Schmittian view," after the Weimar jurist Carl Schmitt, and we will argue that it offers a better picture of the functioning of the administrative state in crisis than the conventional "Madisonian view," which holds that the executive can act only after public debate and Congressional authorization or can, at most, take interim emergency measures until Congress convenes.

The Schmittian view sets outer bounds on political behavior in crises, but does not yield specific explanations of behavior within those bounds. Our second claim thus holds that, within the broad constraints of crisis politics, Congress and the administration had some freedom of action, and their actions differed in the two cases. Most notably, the Bush administration asserted its authority more aggressively after 9/11 than in the financial crisis. In the latter case it bowed to congressional supremacy and eschewed the claims of inherent and exclusive constitutional power it had used to defy statutes in the earlier episode. We argue that these variations in behavior within the constraints reflected rational choices on all sides, given differences in the background political conditions of 2001 and 2008, particularly the Bush administration's loss of popularity and credibility over this period. We therefore reject competing explanations based on differences in the applicable law, in crisis psychology, and other factors.

Part I describes each episode in turn, providing background, basic facts, and an overview of the legal issues. Part II, focusing on the first-decimal similarities, outlines the Schmittian view and suggests that it offers the best account of crisis management in the administrative state. Part III focuses on the second-decimal differences and explains them by reference to rational political behavior, given the actors' preferences and political circumstances. A brief conclusion follows.

\section{Two Crises}

\section{A. 9/11 and Its Aftermath}

Large libraries have been written about 9/11 and its political, economic and legal consequences. We will offer a brief account that is unavoidably selective, picking out 
details that are useful for our later claims. ${ }^{2}$ In later sections, we offer a full treatment of the financial crisis, whose origins, nature and legal implications are largely unexplored.

Economically, the immediate consequences of 9/11 were a massive drop in the stock market, crippling losses in the airline and other transportation sectors, and widespread uncertainty. The Bush administration and Congress responded with a law that bailed out the airlines, ${ }^{3}$ and the economic issues temporarily receded from center stage. Legally and politically, the main focus turned towards counterterror policies and, in 2003, the war in Iraq, which the administration sometimes linked to the counterterror issue.

In the immediate aftermath of 9/11 the legal framework for counterterrorism policy came, for the most part, from the Constitution and from two major statutes: the Authorization for Use of Military Force ${ }^{4}$ enacted on September 17, 2001, and the USA PATRIOT Act, ${ }^{5}$ enacted on October 26, 2001. In subsequent years new statutes were added, notably the Detainee Treatment Act of 2005, ${ }^{6}$ the Military Commissions Act of $2006,{ }^{7}$ and the FISA Amendments Act of $2008 .^{8}$ For present purposes, we focus on the AUMF and the Patriot Act, and their significance for theories of crisis management in the administrative state.

In some cases, the Bush administration initiated or pursued post-9/11 counterterror policies based on claims of inherent executive power stemming from Article II of the Constitution, particularly the Commander-in-Chief clause. In other cases, however, the administration sought legislative authorization for its actions. The September 14, 2001 AUMF gave the administration broad authority to use "necessary and appropriate force” against Al Qaeda and related entities. ${ }^{9}$ How broad this authority actually was became controversial in later years; a plurality of the Supreme Court eventually ruled that it authorized executive detention of enemy combatants, ${ }^{10}$ yet in controversies over surveillance the administration's attempts to invoke the statute were widely rejected. ${ }^{11}$

Civil-libertarian critics derided the "hasty" and "panicked" process by which the AUMF and the Patriot Act were passed, and portrayed them as massive delegations of unchecked power to the executive. The reality, however, was more complex. The

\footnotetext{
${ }^{2}$ For a full treatment, see Eric A. Posner \& Adrian Vermeule, Terror in the Balance: Security, LIBERTY, AND THE COURTS (2007).

${ }^{3}$ See Air Transportation Safety and System Stabilization Act, Pub. L. No. 107-42, 115 Stat. 230 (2001).

${ }^{4}$ Pub. L. No. 107-40, 115 Stat. 224 (2001).

${ }^{5}$ Pub. L. No. 107-56, 115 Stat. 272 (2001).

${ }^{6}$ Pub. L. No. 109-148, div. A, tit. X, 119 Stat. 2739 (2005).

${ }^{7}$ Pub. L. No. 109-366, 120 Stat. 2600 (2006).

${ }^{8}$ Pub. L. No. 110-261, 122 Stat. 2436 (2008).

${ }^{9}$ AUMF §2(b), 115 Stat. at 224.

${ }^{10}$ Hamdi v. Rumsfeld, 542 U.S. 507, 518 (2004) (plurality opinion).

${ }^{11}$ See Letter from Curtis A. Bradley, Richard and Marcy Horvitz Professor of Law, Duke University, et al., to Bill Frist, Majority Leader, United States Senate, et al. (Jan. 9, 2006), available at http://www.fas.org/irp/agency/doj/fisa/doj-response.pdf.
} 
administration partially lost control of the legislative process in both cases, and although it got most of what it wanted, it did not by any means get everything it asked for. Measured from the baseline of the executive's initial proposals, legislative pushback was substantial. However, the larger picture shows a grain of truth in the critics' complaints: measured from the baseline of the legal status quo ante 9/11, the administration did receive large delegations of new powers in response to the crisis.

What about the judges' reaction? Here the picture fits a standard cyclical pattern in American history: courts remain quiet during the first flush of an emergency, and then reassert themselves, at least symbolically, as uncertainty fades and emotions cool. Between 2001 and 2004, the courts were conspicuously silent about counterterror policy. Indeed, in 2003 the Supreme Court denied certiorari in a case questioning the constitutionality of closed hearings in deportation proceedings, despite the existence of a circuit split on the issue ${ }^{12}$ - in tension with the Court's usual certiorari practice, and a clear example of Alexander Bickel's “passive virtues."13

In 2004, the Court for the first time reached the merits of a case about presidential authority over counterterror policy, in Hamdi v. Rumsfeld. ${ }^{14}$ Despite initial impressions that the Court had asserted itself against executive power, the administration won most of what it had wanted. Especially useful to the administration was the plurality's holding that the September 14, 2001 AUMF authorized detention of alleged enemy combatants. ${ }^{15}$ Newspaper accounts and civil libertarians focused on a different holding, that constitutional due process might demand some minimum procedures to determine which detainees are actually enemy combatants. ${ }^{16}$ However, the main opinion conspicuously declined to require that judicial process be used, ${ }^{17}$ and the government constructed a system of administrative tribunals to make enemy-combatant determinations. ${ }^{18}$

By 2006, the Bush administration had lost a great deal of credibility both at home and (especially) abroad, in part because of setbacks in Iraq, in part because of scandals, such as Abu Ghraib, and in part because of spectacular incompetence in the management of Hurricane Katrina. Moreover, with the passage of time and the absence of new terrorist attacks in the homeland, the sense of threat waned. Predictably, the judges reasserted

\footnotetext{
${ }^{12}$ See North Jersey Media Group, Inc. v. Ashcroft, 308 F.3d 198 (3d Cir. 2002), cert. denied, 538 U.S. 1056 (2003).

${ }^{13}$ See Alexander M. Bickel, The Least Dangerous Branch: The Supreme Court at the Bar of Politics (1962).

${ }^{14} 542$ U.S. 507 (2004).

${ }^{15}$ See id. at 517.

${ }^{16}$ See, e.g., Linda Greenhouse, The Supreme Court; Detainees; Access to Courts, N.Y. TIMES, June 29, 2004, at A1.

${ }^{17}$ See, e.g., Hamdi, 542 U.S. at 538 ("There remains the possibility that the standards we have articulated could be met by an appropriately authorized and properly constituted military tribunal.”).

${ }^{18}$ See Memorandum from Paul Wolfowitz, Deputy Sec'y of Def., to the Sec'y of the Navy (July 7, 2004), available at http:// www.defenselink.mil/news/Jul2004/d20040707review.pdf (establishing Combatant Status Review Tribunals.)
} 
themselves. In Hamdan v. Rumsfeld in 2006, the Court held that the administration's military commissions set up to try alleged enemy combatants for war crimes violated relevant statutes and treaties. ${ }^{19}$ When Congress reacted by passing the Military Commissions Act in 2006, the Court went on to hold in 2008, in Boumediene v. Bush, that the statute violated the Suspension Clause of the Constitution by denying habeas

corpus to detainees at Guantanamo Bay. ${ }^{20}$ Even in these cases, however, the Court did not actually order anyone released; in both cases, the result was simply more legal process. There remain sharp pragmatic limits on what courts are willing to do when faced with executive claims of security needs.

\section{B. The Financial Crisis}

\section{The Origins of the Crisis}

Financial crises are less familiar than security crises, and the September 2008 financial crisis has been less studied than the conflict with Al Qaida, so we will provide a more detailed account of its background and development.

A financial crisis occurs when people stop extending credit to other people because they fear that the loans will not be repaid. Modern financial regulation emerged from the recognition that financial crises are inevitable in an unregulated market, and that they can lead to economic collapse, political instability, and widespread misery. Consider a typical bank. Banks are intermediaries that bring together creditors who have accumulated capital and want to save it (depositors and other savers) and borrowers who have insufficient capital for their purposes-consumers, who seek to purchase a durable good which they will enjoy over a period of time, and businesses, which seek to make investments. The bank takes funds from the creditors and extends them to the debtors, making its profits by charging a higher interest rate to the debtors than it pays to the creditors.

The bank attracts many of its creditors by giving them the right to withdraw their funds on demand; it attracts many of its debtors by permitting them the right to pay back over a long period of time. In normal times, creditors are constantly withdrawing and depositing but in aggregate they leave a relatively fixed sum in the bank's coffers, so that the bank can turn it over to its long-term debtors without worrying that it will have to pay more funds to its creditors than it has on hand. The bank will keep some funds on handa capital cushion - to ensure that it can cover small withdrawal spikes. If some eventsay, the closure of a local factory - causes a temporary increase in withdrawals, the bank can cover these withdrawals by borrowing from other banks with excess capital, while in the meantime slowing down its long-term lending if there is a general economic slowdown. The whole system works because depositors assume that banks will pay them

\footnotetext{
${ }^{19} 548$ U.S. 557, (2006).

${ }^{20} 128$ S. Ct. 2229 (2008).
} 
back if they withdraw their money, banks assume that they can borrow from other banks, and so on.

A bank run occurs when depositors believe that the bank does not have enough funds to pay them back. A run typically occurs as a result of some real or rumored event that suggests that a bank may be, or become, insolvent. Suppose, for example, that people believe that a bank manager has embezzled funds from the bank, depleting its assets. A few risk-averse depositors withdraw their assets as a precaution, but when others hear about these withdrawals, they fear that the bank will not have enough funds left to cover their own withdrawals, and so forth, leading to a run. A run can be stopped if the bank can borrow from other banks or institutions; as people realize that the bank will honor their withdrawals, they feel less urgency about withdrawing. But if the rumored or real events reflect a systemic problem-suppose people believe that there is an economic downturn, which will lead to unemployment, which will lead to default by borrowers, which will prevent banks from covering withdrawals-all banks will be subject to runs, and so they will not be able to lend to each other. Indeed, banks may fear lending to a particular bank that is subject to a run because they believe that that bank will still lose all its depositors and thus be unable to repay the interbank loan. A collapse of banking can ensue.

The main implication is that the financial system can collapse merely because of a crisis of confidence, rather than because of some underlying economic problem. If everyone believes that all banks will fail, and withdraws his or her deposits, then all banks will fail. People put their money under their mattresses rather than in banks, which means that banks have no money to lend to consumers and businesses. The businesses cannot meet their payrolls and so must fire employees, who cannot repay their mortgages or buy goods from other businesses, and so forth.

These problems were widely recognized long ago; the modern system of banking regulation was finally put in place in the Great Depression, though it would continue to evolve. Essentially, the government acts as the lender of last resort: it guarantees that banks will have enough funds to cover deposits. This guarantee takes the form of deposit insurance as well as a more informal commitment by the central bank, the Fed, to lend money at low rates of interest to banks in financial distress. But the guarantee creates the problem of moral hazard: because banks that make risky decisions know that the government will rescue them if bad outcomes occur, while they enjoy the full payoff if the decisions turn out well, they have an incentive to engage in those risky decisions. So the government supervises banks; among other things, it requires them to maintain a certain level of capital, so that they can cover withdrawals most of the time. Various other restrictions have been imposed. ${ }^{21}$

\footnotetext{
${ }^{21}$ For an overview of regulation of financial institutions, see HowELL E. JACKSON \& EDWARD L. SYMONS JR., REGULATION OF FinANCIAL INSTITUTIONS (1999).
} 
No one ever believed that the regulatory system was foolproof. Financial panics happen as a result of complicated economic and psychological factors that are hard to predict and control. ${ }^{22}$ The Fed and other government institutions must exercise judgment when responding to them: if they are too aggressive, they exacerbate the problem of moral hazard and can produce other adverse economic effects; if they are not aggressive enough, financial crises will not be prevented or resolved. To some extent they are inevitable, and the financial crisis of 2008 was surely due in part to factors that simply cannot be controlled.

Otherwise, analysts identify a number of contributing factors to the 2008 crisis. $^{23}$ Housing prices rose rapidly in the 1990s and early 2000s, stimulated both by the rapid economic growth of that period, which made people optimistic about their employment prospects and future income, and by very risky lending to people without the financial wherewithal to repay their loans unless housing prices would continue to rise indefinitely. Thanks to innovations in the design of financial instruments, and to aggressive government support for mortgage lending, lenders could lend money and then sell the loan to others, who would bear the risk of nonpayment. The lenders thus had little incentive to ensure that the borrower was not too risky, and in many instances engaged in fraud to ensure that downstream buyers would believe that the borrower was less risky than he or she in fact was. The loans were pooled and securitized, which means that the streams of payments were divided up and packaged with other payment streams resulting from other loans; people could trade these rights. Traders may not have worried much about bad loans because they could diversify by purchasing different types of securities (they were classified according to risk) and adding them to portfolios that included other types of assets. And to the extent that traders did worry about the value of the mortgagebacked securities they held, they could reduce the risk they faced (or so they thought) by engaging in credit default swaps, which were essentially insurance transactions, where a third party would promise to pay the counterparty if the latter's mortgage-back securities lost value as a result of default on the underlying mortgages. These third parties would charge premiums to cover the risk they were taking on, and employed sophisticated trading strategies to minimize the risk that they took on-for example, short selling the securities of other holders of the mortgage-backed securities as mortgage default rates increased.

\footnotetext{
${ }^{22}$ The economic literature contains two theories: one is that panics are random (see Douglas Diamond \& Philip H. Dybvig, Bank Runs, Liquidity, and Deposit Insurance, 91 J. PoL. ECON. 401 (1983)); the other is that they are due to asymmetric information (see Charles W. Calomiris \& Gary Gorton, The Origins of Banking Panics: Models, Facts and Bank Regulation, in FinANCIAL MARKETS AND FINANCIAL CRISES 109 (R. Glenn Hubbard ed., 1992)).

${ }^{23}$ See, e.g., Tyler Cowen, Three Trends And a Train Wreck, N.Y. TIMES, Oct. 19, 2008, at BU6 ("the three fundamental factors behind the crisis have been new wealth, an added willingness to take risk and a blindness to new forms of systematic risk"); Jon Hilsenrath, Serena Ng \& Damian Paletta, Worst Crisis Since '30s, With No End Yet in Sight, WALl St. J., Sept. 18, 2008, at A1 (discussing various contributors).
} 
The securitization of mortgages was not a new phenomenon, and housing prices had risen and fallen before. The magnitude of the financial crisis was probably due to the trillion-plus dollar market in credit default swaps. ${ }^{24}$ Investment banks would buy pools of mortgages and create instruments that gave buyers rights to various slices of the pooled revenue streams - say, just the principal on a certain class of subprime mortgage, or just the interest payments on another class of high-grade mortgage. Buyers of these instruments may not have fully understood their riskiness or how to price them; even if they did, many buyers had strong incentives to purchase them. An institution that purchased these instruments could evade minimum capital requirements and add enormous leverage to their portfolios, while regulators such as the SEC looked the other way. ${ }^{25}$ This allowed them to make spectacular profits during boom times but threw them into insolvency when the boom times ended.

Housing prices peaked in 2005-2006. The collapse that followed could well have been a cyclical phenomenon - the standard bust that follows a boom when investors overestimate the demand for a product and overbuild. But easy credit for home buyers exacerbated the problem. As housing prices fell, mortgage holders found that they could not avoid default by selling their houses, which were sold in foreclosure. As foreclosure rates increased, the value of mortgage-backed securities fell. Investment banks that held mortgage-related securities were required, by mark-to-market regulations, to lower the value of these securities in their portfolios. As the value of their assets fell, these financial institutions became insolvent. They had hedged the risk by purchasing derivatives but these derivatives turned out to be worthless because counterparties also became insolvent. Banks did not have to mark down their mortgage-related assets but by the same token their own lenders could not price those assets, could not assume that the banks were creditworthy, and thus became reluctant to lend to them. As is always the case in financial crises, the government faced a dilemma. If it let firms fail, they would be appropriately punished for their excessively risky investments. But they would also bring down other firms, with the result that credit would dry up, and economic activity would be stifled. After some hesitation-Lehman was allowed to fail with disastrous short-term consequences because so many other firms had accounts with Lehman ${ }^{26}$ - the Fed and other government institutions began pumping liquidity into the system at unprecedented levels. They were apparently persuaded by the scale of the failures, the quite obvious

\footnotetext{
24 See Gary Gorton, The Panic of 2007 (Sept. 2008) (unpublished manuscript, available at http://www.nber.org/papers/w14358.pdf).

${ }^{25}$ See Edmund L. Andrews, Michael J. de la Merced, \& Mary Williams Walsh, Fed in an $\$ 85$ Billion Rescue of an Insurer Near Failure, N.Y. TIMES, Sept. 17, 2008, at A1; Floyd Norris, Out of the Shadows and Into the Harsh Light, N.Y. TIMES, Sept. 27, 2008, at C3; Stephen Labaton, S.E.C. Concedes Oversight Flaws Fueled Collapse, Sept. 27, 2008, at A1.

${ }^{26}$ See Floyd Norris, After Weekend Full of Talks, No Sign of a Lending Thaw, N.Y. TimEs, Oct. 13, 2008, at B1; Louise Story \& Ben White, The Road to Lehman's Failure Was Littered With Lost Chances, N.Y. Times, Oct. 6, 2008, at B1; Joe Nocera, 36 Hours of Alarm and Action as Crisis Spiraled, N.Y. Times, Oct. 2, 2008, at A1.
} 
contagion effect, and independent evidence of a credit crunch, such as the extremely high rate of interest that banks began to charge each other for interbank loans.

It soon became clear that a case-by-case approach would not be sufficient to address the financial crisis. For one thing, the financial crisis would require more resources than the Fed could supply. On September 19, Henry Paulson, the Treasury Secretary, submitted a bill to Congress that would authorize Treasury to borrow $\$ 700$ billion and use it to purchase mortgage-related assets. The bill provided that the Secretary's purchasing decisions would be final, not subject to judicial review. Paulson apparently believed that by purchasing mortgage-related assets, the government would help reduce uncertainty about banks' balance sheets, allowing them to borrow if they turned out to be solvent. Judicial review or other oversight would slow down this process when quick action was essential.

The boldness of the Secretary's bill initially produced an enthusiastic reaction, and the financial markets rose, but quickly the reception turned sour. Critics argued that the bill was a "blank check" that gave the Treasury too much discretion and subjected it to too little oversight; that the bill favored the rich-the investment banks, their managers, their shareholders - at the expense of the taxpayer, while providing no relief to distressed homeowners; and that Secretary Paulson, with the support of Bernanke, sought to stampede Congress into action by holding out dire consequences if inaction occurred, rather than acknowledging that Congress should hold hearings, solicit the advice of independent experts, and deliberate. ${ }^{27}$

House leaders of both parties, with the support of Paulson, President Bush, and both candidates for the presidency, greatly expanded the Paulson bill, partly in response to these criticisms, but on September 29, the House voted down the revised version by a vote of 228 to 205. The stock market crashed, with the Dow Jones Index falling by 778 points. Senate leaders promptly took up the bill and overwhelmingly passed a revised version on October 1 . The Senate version largely retained the provisions of the House bill but added numerous, mostly unrelated provisions designed to appeal to the marginal dissenters. On October 3 this bill passed the House and was signed by the president. ${ }^{28}$

The Emergency Economic Stabilization Act of $2008^{29}$ (EESA) differed from the Paulson bill in numerous ways. But most important, for our purposes, it did not reduce Treasury's power to purchase mortgage-related securities; in fact, it expanded Treasury's

\footnotetext{
${ }^{27}$ See Letter from Professor Daron Acemoglu, et al., to the Speaker of the House of Representatives and the President Pro Tempore of the Senate (Sept. 24, 2008), available at http://faculty.chicagogsb.edu/john.cochrane/research/Papers/mortgage_protest.htm; see also David $\mathrm{M}$. Herszenhorn, Stephen Labaton, \& Mark Landler, Democrats Set Conditions as Treasury Chief Rallies Support for Bailout, N.Y. TIMES, Sept. 22, 2008, at A1.

${ }^{28}$ See David M. Herszenhorn, Bush Signs Bill, N.Y. Times, Oct. 4, 2008, at A1; Carl Hulse \& Robert Pear, Adding Sweeteners, Senate Pushes Bailout Plan, N.Y. Times, Oct. 1, 2008, at A1.

${ }^{29}$ Pub. L. No. 110-343, div. A [hereinafter "EESA"].
} 
power, authorizing it to purchase virtually any security when doing so could help resolve the financial crisis. ${ }^{30}$ Democrats in Congress also sought to compel Treasury to regulate executive compensation and provide relief to homeowners subject to foreclosure in limited circumstances, but the authorities they gave Treasury were largely discretionary. EESA also provided for limited judicial review and set up various oversight mechanisms that, however, lacked coercive power.

Even before Treasury put into operation its plan to purchase mortgage-related assets, it became clear that this approach would not be adequate, and Treasury announced that it would inject equity directly into financial institutions by buying preferred stock, as the Fed did with AIG. Meanwhile, the Fed was increasing the money supply, buying up commercial paper, and purchasing other assets that it traditionally left to the private markets. Treasury directed Fannie Mae and Sallie Mae to buy up mortgage-backed securities. The FDIC was brokering purchases of failed banks such as Wachovia, ${ }^{31}$ and, citing its emergency statutory authority, it eliminated the $\$ 250,000$ ceiling on deposit insurance and guaranteed virtually all newly issued senior unsecured debt, potentially exposing itself to more than $\$ 1$ trillion in liability. ${ }^{32}$

\section{Legal Issues}

Actions Based on Existing Statutory Authority. The EESA was proposed and enacted in part to clarify the agencies' statutory authority. Most of the actions taken by the Treasury Department, the Federal Reserve Board, the SEC, and related agencies fit within existing statutory authorities, but not all did. The most legally questionable event was the bailout of AIG, which preceded the EESA's passage.

AIG is the largest insurance company in the United States. When AIG was required to mark down its mortgage-related assets, and to make good on its obligations under its credit default swaps, it became insolvent. This meant that thousands of clients who believed that they had insurance against various adverse events suddenly could not expect to receive a full payout if those events occurred. Those clients would need to either self-insure, by liquidating assets, or to purchase additional insurance, which would also require liquidating assets, driving down their prices and contributing to the financial contagion. $^{33}$

The only way to stop financial contagions is to persuade creditors (the insurance clients) that they will be paid in full. With respect to banks, the government guarantees

\footnotetext{
${ }^{30}$ See id. $\S \S 3,103$.

31 Deborah Solomon \& Damian Paletta, U.S. Bailout Plan Calms Markets, But Struggle Looms Over Details, Wall ST. J., Sept. 20, 2008, at A1; Vikas Bajaj \& Michael M. Grynbaum, Amid Global Worry, Central Banks Try to Come to Credit Markets’ Aid, N.Y. TimES, Sept. 30, 2008, at A1.

32 See FDIC, FDIC Announces Plan to Free Up Bank Liquidity, Oct. 14, 2008, http://www.fdic.gov/news/news/press/2008/pr08100.html.

33 See Edmund L. Andrews, Michael J. de la Merced, \& Mary Williams Walsh, Fed in an §85 Billion Rescue of an Insurer Near Failure, N.Y. TIMES, Sept. 17, 2008, at A1.
} 
deposits, and the Fed can step in and make loans to banks threatened by runs, so that creditors will not call in loans just because they fear similar action by other creditors. The same logic applies to an insurance company, and the Fed could, in principle, rescue AIG by making loans to it. The problem raised by the AIG case is that AIG was not a bank. The Fed normally lends to banks and not to other institutions.

However, a Depression-era statute gave the Fed the power to make loans to nonbanks in emergency conditions. ${ }^{34}$ Citing this authority, the Fed made what it called a secured loan to AIG. ${ }^{35}$ Under the terms of this transaction, AIG would borrow $\$ 85$ billion over two years, at the rate of three-month LIBOR (the interest rate charged on interbank loans, which was three percent at the time of the transaction) plus 8.5 percent. All of AIG's assets provided collateral for the loan; and the U.S. Treasury would end up the beneficiary of a trust holding 79.9 percent of AIG's stock. Finally, the Fed replaced AIG's CEO and obtained undisclosed rights to control the operation of the business. ${ }^{36}$

Although a loan in form, the transaction was a purchase in substance: the Fed was given the incidents of ownership in the form of most of the stock. If the transaction was in substance a purchase of AIG, then it was not authorized by the statute, which permitted only loans. A complicating factor is that under the Chevron doctrine, courts generally defer to agencies' reasonable interpretations of statutes they administer, at least if those interpretations are issued in a procedurally proper format. ${ }^{37} \mathrm{~A}$ court might find that, in the circumstances, the Fed's implicit interpretation of the statute to permit purchases of distressed non-bank firms in emergency conditions was reasonable.

The Nondelegation Doctrine and Nondelegation Canons. An even larger complicating factor, both in the AIG case and in the case of the EESA, involves the "nondelegation doctrine." The doctrine holds that Congress must supply an intelligible principle to guide the policymaking discretion of agencies. Failing this, Congress has entrusted the agencies with legislative rather than executive power, in violation of Article $\mathrm{I}^{38}$ In practice, the nondelegation doctrine is largely moribund at the level of

\footnotetext{
${ }^{34}$ Federal Reserve Act § 13(3), 12 U.S.C. § 343 (2000).

${ }^{35}$ Press Release, Federal Reserve Board, Federal Reserve Board, With Full Support of the Treasury Department, Authorizes the Federal Reserve Bank of New York to Lend Up to \$85 Billion to the American International Group (Sept. 16, 2008) (available at http://www.federalreserve.gov/newsevents/press/other/20080916a.htm).

${ }^{36}$ See American International Group, Credit Agreement Between American International Group, Inc. and Federal Reserve Bank of New York (Ex. 99.1) (Sept. 22, 2008), available at http://www.sec.gov/Archives/edgar/data/5272/000095012308011496/y71452exv99w1.htm.

${ }^{37}$ United States v. Mead Corp., 533 U.S. 218 (2001). For deference to Treasury on questions of law, and Treasury's legal position within the standard framework of administrative law and the Administrative Procedure Act, see Kristin E. Hickman, Coloring Outside the Lines: Examining Treasury's (Lack of) Compliance With Administrative Procedure Act Rulemaking Requirements, 82 NOTRE DAME L. REV. 1727 (2007).

${ }^{38}$ See Whitman v. Am. Trucking Assn's, 531 U.S. 457, $472-73$ (2001); Mistretta v. United States, 488 U.S. 361 (1989) (Scalia, J., dissenting). In an alternative formulation, the forbidden line is crossed, not when Congress entrusts the executive with any legislative power at all, but when Congress entrusts the executive
} 
constitutional law; it was invoked to invalidate legislation for the first time in 1935, and for the last time in $1936 .{ }^{39}$ At the level of statutory interpretation, however, the doctrine is occasionally invoked as an interpretive canon, in which agency authority is construed narrowly in order to avoid the constitutional question of nondelegation. ${ }^{40}$

Treasury's initial proposal would have granted the Secretary sweeping authority largely without explicit standards and without any judicial review. The final version of the EESA actually expanded the Secretary's authority along important margins, although it also introduced some oversight mechanisms and some judicial review, as we will discuss below. Given the breadth of authority it delegates, a colorable nondelegation challenge might be made against the EESA. A challenge of that sort might emphasize that, when the Court invalidated the National Industrial Recovery Act in 1935, it described the statute as granting the President power over the entire national economy, essentially enabling an economic dictatorship. ${ }^{41}$ Perhaps the EESA is not entirely dissimilar, at least in the sense that the EESA will affect the entire economy, directly or indirectly, and that the power to spend $\$ 700$ billion or more ${ }^{42}$ represents a large-ish chunk of money and discretionary authority for any one administrator to possess. Furthermore, the Court's last major pronouncement on the constitutional nondelegation doctrine, Whitman v. American Trucking Associations, ${ }^{43}$ articulated a sliding-scale approach, under which a delegation conferring greater discretion requires more clarity and specificity in its guiding principles. ${ }^{44}$

For several reasons, however, such a challenge is highly unlikely to succeed. First, the enacted statute contains more in the way of explicit intelligible principles and standards than did the initial proposal. The main purpose is to "immediately provide authority and facilities that the Secretary of the Treasury can use to restore liquidity and stability to the financial system of the United States." 45 Whether or not the grant of such authority or its exercise will have those effects, the statute's purpose is perfectly

with legislative power that is not adequately cabined. Whitman, 531 U.S. at 487-90 (Stevens, J., concurring in part and concurring in the judgment). This difference is strictly semantic and makes no difference for our purposes.

${ }^{39}$ See A.L.A. Schechter Poultry Corp. v. United States, 295 U.S. 495 (1935); see also Carter v. Carter Coal Co., 298 U.S. 238 (1936).

${ }^{40}$ See Indus. Union Dep’t, AFL-CIO v. Am. Petroleum Inst. (Benzene), 448 U.S. 607, 646 (1980) (plurality opinion); FDA v. Brown \& Williamson Tobacco Corp., 529 U.S. 120, 133, 160-61 (2000); see also John F. Manning, The Nondelegation Doctrine as a Canon of Avoidance, 2000 Sup. CT. REV. 223; Cass R. Sunstein, Nondelegation Canons, 67 U. CHI. L. REV. 315 (2000).

41 Schechter, 295 U.S. at 541-42. However, another theme in Schecter was that the NIRA in effect delegated lawmaking power to private parties, see id. at 537, and that claim has no obvious parallel in the EESA.

${ }^{42}$ The Secretary can draw on a maximum of $\$ 700$ billion at any one time, but the total might be more. See EESA § 115(a)(3).

${ }^{43} 531$ U.S. 457 (2001).

${ }^{44}$ Id. at 475.

${ }^{45}$ EESA $\S 2$. 
intelligible. And the statute contains an explicit list of rather detailed "considerations" that the Secretary must take into account when exercising his authority. ${ }^{46}$

Second, courts have sometimes read legislation to contain implicit standards, drawn from the legislative background and statutory purposes, in order to pretermit a nondelegation challenge, ${ }^{47}$ and that course of action would seem highly probable with respect to the EESA, even if the statute's explicit standards are insufficient. Courts might read the legislation to implicitly embody a general intelligible principle that the Secretary's powers is to be used in order to promote liquidity, to raise confidence, to dampen uncertainty, to stabilize markets, or some mix of all of these. The legislative history is of course extremely thin, as is usually the case with emergency statutes, but the broader legislative background contains ample references to these and related ideas.

Third, any of these standards and principles would make the EESA at least as intelligible as other statutes the Court has upheld against nondelegation challenge. These include statutes giving agencies power to regulate "in the public interest" and, most recently, in Whitman, a statute giving EPA the authority to regulate pollutants in a manner "requisite to protect the public health." ${ }^{\text {"48 }}$ If such precedents are any guide, it is unlikely in the extreme that the Court would invalidate the EESA on nondelegation grounds.

That said, the nondelegation canon might be invoked at the level of statutory interpretation. In the case of the EESA the Treasury's substantive authority is quite clear, so the more likely use of the nondelegation canon would be to narrow the Fed's authority under the 1932 statute used to "loan" money to AIG. In recent cases, the Court has refused to construe ambiguous statutes, and even not-so-ambiguous statutes, to give agencies discretion over "major questions" of policy ${ }^{49}$; a clear statement from Congress is said to be necessary in such circumstances. Indeed, is possible that lingering concerns over the legal status of the AIG bailout, for which statutory authority was somewhat ambiguous, were part of the impetus for the EESA. The statute gives the Treasury clear authority to make purchases from distressed firms, whereas the Fed has such authority only under a flexible reading of the 1932 law.

Judicial Review. The Secretary's initial proposal would have precluded any judicial review of his discretionary decisions under the statute. Lawyers and others reacted by saying that the preclusion would give the Secretary unchecked power; they meant power with no legal checks, although political checks would continue to operate. In response, the enacted version of the legislation provided for standard APA-style

\footnotetext{
${ }^{46} I d . \S 103$.

${ }^{47}$ See Amalgamated Meat Cutters v. Connally, 337 F. Supp. 737, 757 (D.D.C. 1971) (Leventhal, J., for three-judge panel).

${ }^{48}$ Whitman, 531 U.S. at $472-76$.

${ }^{49}$ See Cass R. Sunstein, Chevron Step Zero, 92 VA. L. REV. 187, 231-47 (2006).
} 
arbitrariness review. However, in an example of "studied ambiguity" haste, the statute also prohibited injunctions or other equitable relief against the Secretary's actions under some of the main provisions of the Act, despite the fact that APA-style review is itself equitable. ${ }^{51}$ A plausible reconciliation of these provisions is that Congress merely intended to bar parties from obtaining advance relief against the Secretary's decisions, while still allowing parties to obtain relief after the fact, but this is hardly pellucid.

So the judicial review provisions of the EESA are confusing, but it is clear that the statute provides for more than zero judicial review, in contrast to the initial proposal. For present purposes, the availability of at least some review has a double significance. First, there is the question how much judicial oversight the review provisions will enable, in practice; we take up that issue in Part II, suggesting that judicial review under the EESA will quite predictably prove highly deferential.

Second, the availability, or not, of judicial review might be a factor in the nondelegation analysis. At least on an older view, judicial review helps to ensure against arbitrary administrative action and thereby substitutes for legislative oversight. ${ }^{52}$ The absence of review would exacerbate any nondelegation problems, but the availability of review under the actual legislation would be yet another reason for thinking that a constitutional nondelegation challenge would make little headway. However, all this may be a red herring in any event. A view with more recent support is that nondelegation is strictly a question about whether the relevant statute creates a substantive intelligible principle to guide the executive; judicial review is a separate question, one that is neither here nor there. Although the latter view is implicitly suggested by the logic of Whitman v. American Trucking, the Court has not issued a clear statement about the question. ${ }^{53}$

\section{Crisis Management in the Administrative State: A Schmittian View}

Against this legal and economic background, what explains how institutions and actors behaved? Many discussions of crisis management and emergency lawmaking have two main flaws. First, they focus on historical episodes from the Civil War or earlier, overlooking that the central problems of crisis management today involve the role of the administrative state. By contrast, we will focus on a nearly synchronic comparison between the 9/11 crisis and its aftermath, on the one hand, and the 2008 financial crisis, on the other. In both episodes, administrative agencies have been central actors.

\footnotetext{
${ }^{50}$ Cf. Posting of Rick Pildes to Balkinization, http://balkin.blogspot.com/2008/09/update-revising-powersof-secretary-of.html (Sept. 28, 2008, 17:14 EST).

${ }^{51}$ See EESA § 119(a)(2).

${ }^{52}$ See, e.g., Amalgamated Meat Cutters, 337 F. Supp. at 746.

${ }^{53}$ Compare Defenders of Wildlife v. Chertoff, 527 F. Supp. 2d 119 (D.D.C. 2007) (three-judge court), cert. denied, 128 S.Ct. 2962 (2008), which upheld, against a nondelegation challenge, a statute giving the Secretary of Homeland Security unreviewable authority to waive multiple federal statutes in order to speed up the building of a fence along the U.S.-Mexico border.
} 
Secondly, even discussions that do take account of the administrative state tend to ignore political constraints. They ask how authority to manage crises should be allocated among Congress, the President, executive agencies, independent agencies, and the courts, as though all possible choices are on the table and everything is up for grabs. We will suggest, to the contrary, that the beginning of wisdom on this subject is to recognize the tight constraints that the possible places on the desirable. Ought implies can; before asking what authority institutions ought to have to manage crises, we must ask what their capacities are, and what allocations of authority are feasible given those capacities.

This sort of analysis will have indirect normative implications, but largely negative ones. In this Part, we will argue that the conditions of the administrative state make it practically inevitable that the executive and the agencies will be the main crisis managers, with legislatures and courts reduced to adjusting the government's response at the margins and carping from the sidelines. Congress and the courts suffer from crippling institutional debilities as crisis managers; legislators and judges are aware of this, and do what they have no real choice but to do, which is delegate sweeping power to the executive to cope with the crisis. In Part III, we will go on to explain how officials behaved, within the broad constraints we have identified. In particular, we ask whether officials acted irrationally in these episodes, given their political circumstances; our answer is no.

\section{A. Common Features}

The preconditions for both crises developed through the ordinary workings of history, well before the crises burst onto the scene. The 9/11 security crisis can be traced to the 1991 Gulf War, when Saudi Arabia turned down Osama bin Laden's offer of protection from Iraq, which had just invaded Kuwait, and accepted American protection; other complex foreign policy decisions related to the United State's engagement in the middle east also contributed to the conflict with Al Qaida. The 2008 financial crisis also has nearer and more distant origins. The vulnerability of the financial system to the housing bubble had a tangle of causes, including deregulation and lax oversight going back to the 1990s, the globalization of the financial system as a result of technological innovation, and the invention of sophisticated financial instruments that allowed investors to spread their risks but that also had the effect of increasing systemic risk.

In both cases, the crisis began when events - the 9/11 attack, the failure of numerous large financial institutions in a short time period-revealed the existence of a serious threat to security in one case and to economic well-being in the other. Government officials and private observers had for a long time understood that Al Qaida could launch a devastating terrorist attack and that turmoil in the housing and subprime mortgage markets could lead to a financial meltdown, but the dangers in both cases were highly uncertain, and elected officials could not be persuaded to devote significant 
resources to these problems. ${ }^{54}$ The crisis revealed the extent of the danger and the executive branch responded with alacrity.

In both cases, at the onset of the crisis the executive acted immediately and sought authorization from Congress. In the 9/11 crisis, the Bush administration shut down air travel, directed security personnel to guard against further attacks, swept up thousands of undocumented aliens from Muslim countries, and engaged in ethnic profiling. Meanwhile, it went to Congress and obtained a very broad delegation-the Authorization to Use Military Force-which would allow it to engage in combat operations against suspected members of Al Qaida and affiliated groups around the world, and to launch an invasion of Afghanistan. It also submitted the Patriot Act to Congress, which would give law enforcement officials various search and surveillance tools. Notably, the Bush administration also defied several existing statutory schemes rather than seeking to have them changed: the ban on torture, restrictions on surveillance in FISA, and (arguably) a law against detention of U.S. citizens.

In the financial crisis, the Bush administration-including the Federal Reserve Board, a legally independent agency that acted in close collaboration with the Treasuryalso relied heavily on statutory authorities. The bailouts of Fannie Mae, Sallie Mae, Bear Stearns, and AIG were conducted pursuant to statutes that authorize the Fed to make loans to banks and, in emergencies, other businesses whose failure threatens the health of the financial system. But the Bush administration also submitted a bill to Congress that would give Treasury power to purchase mortgage-related assets from distressed firms, including the authority to spend up to $\$ 700$ billion for this purpose. Congress initially rejected the bill, but a modified version that gave Treasury more power than it initially sought, albeit subject to greater oversight as well, was enacted only two weeks after the Bush administration's proposal was sent to Congress.

Overall, the politics of the two crises had four major features in common. First, a publicly observable event occurred. In 2001, four planes were hijacked, and three crashed into buildings, killing more than 3,000 people. In 2008, highly visible financial institutions with household names collapsed or teetered on the abyss, the stock market plunged, and various indicators of the ill health of credit markets reached unprecedented levels. ${ }^{55}$ Second, the events revealed a threat about which ordinary people and many experts previously knew little or nothing. The visibility of the threat confirmed, for ordinary people, the nature of the threat to which experts testified. Third, the threat

\footnotetext{
${ }^{54}$ Which could well have been rational. See Anup Malani \& Albert Choi, Rational Crises (unpublished manuscript, 2008) (proposing a model that shows that governments use crises to distinguish between credible and non-credible assertions that a government response is needed for a problem).

${ }^{55}$ For example, the Ted spread and the VIX. See Edmund L. Andrews, As Economy Weakens, Federal Reserve Officials Consider Lowering Rates, N.Y. TimEs, Oct. 3, 2008, at C4 (Ted spread); Sarah Lueck, Damian Paletta \& Greg Hitt, Bailout Plan Rejected, Markets Plunge, Forcing New Scramble to Solve Crisis, WALl ST. J., Sept. 30, 2008, at A1 (VIX).
} 
revealed by the crisis was complex and ambiguous, and the proper response to the threat was highly uncertain. Only experts could really understand the threat-perhaps only experts with security clearances or access to privileged information. However, the experts disagreed among themselves and could not adequately explain their views to the public or even to politicians. Fourth, and related, a general view emerged that the executive needed additional discretion (as well as resources) in order to address the threat adequately. This view held that Congress must grant new authority or relax existing constraints on executive action. And Congress did in fact do so, delegating sweeping new powers to the executive, although with some qualifications at the margin and with oversight mechanisms of uncertain force.

\section{B. The Schmittian View}

Why do crises pose distinctive problems for democratic governance? One might deny that they do. On this view, crises do not belong in a category of their own; they are just the endpoint of a continuum along which the magnitude of a threat increases. Ordinary criminal behavior can have devastating effects but no one believes that its existence creates a crisis. Police, prosecutors, and other executive officials are given some discretion, but their statutory authority is circumscribed and their decisions are subjected to ordinary judicial review. The emergence of a terrorist threat is, like the crack epidemic, just a new type of criminal problem, necessitating perhaps increased resources for the police and the construction of prisons, but not any significant change in how the legal system operates.

Similarly, one might point out that the economy always experiences "too much" or "too little" lending, against some baseline of optimal social welfare. Institutions are set up to inject and extract liquidity as circumstances warrant, and to ensure that creditors and debtors do not exploit these types of government intervention in a manner that harms public welfare. A financial crisis is just the extreme end of a continuum of liquidity, requiring perhaps greater resources but no real change in the operation of institutions.

Whatever the merits of that view, this is not what happens during crises. Instead, fundamental institutional reform takes place in a brief period of time even as existing institutions struggle to fulfill their mandate. Sometimes, existing institutions simply claim more power than it was understood that they had. At other times, Congress rouses itself to act, but only for the purpose of confirming a seizure of power or discretion by the executive, or in order to delegate large new powers. Our goal is to understand these dynamics.

To do so, we turn to the best general analysis of institutional capacities and crisis management in the administrative state, stemming from Carl Schmitt. A main theme in Schmitt's work involves the relationship between the classical rule-of-law state, featuring legislative enactment of general rules enforced by courts, and the administrative state, featuring discretionary authority and ad hoc programs, administered by the executive, 
affecting particular individuals and firms. We do not need, and will dispense with, some of Schmitt's more jurisprudential and abstract claims and concerns, such as his critique of legal positivism. Rendered in suitably pragmatic terms, Schmitt's work contains essential insights for understanding how Congress, the courts and the executive can and cannot manage crises, economic or otherwise.

Here the main inspiration is not solely Schmitt's famous work on emergencies, on "the exception" as opposed to normal law, or his famous pronouncement that "sovereign is he who decides on the exception."56 Although we will draw on those themes when relevant, we also draw on Schmitt's analysis of the general debility of legislatures and judges in the modern administrative state, not only in times of war but also or especially in economic crises. ${ }^{57}$ Such crises underscore legislative debility, making it plain for all to observe, but the causes of the debility are structural.

The nub of Schmitt's view is his idea that liberal lawmaking institutions, such as legislatures and courts, "come too late" to crises in the modern state. Those institutions frame general norms that are essentially "oriented to the past," whereas "the dictates of modern interventionist politics cry out for a legal system conducive to a present- and future-oriented steering of complex, ever-changing economic scenarios." ${ }^{28}$ Legislatures and courts, then, are continually behind the pace of events in the administrative state; they play an essentially reactive and marginal role.

Legislatures may be asked to delegate new authority to administrators after a crisis is already underway, but the frontline response is inevitably administrative, and the posture in which legislators are asked typically to grant new delegations of authority, with the crisis looming or in full blast, all but ensures that legislators will give the executive much of what it asks for. Courts, for their part, get involved only much later, if at all, and essentially do mop-up work after the main administrative programs and responses have solved the crisis, or not. The result is that in the administrative state, broad delegations to executive organs will combine lawmaking powers with administrative powers; "only then can the temporal distance between legislation and legal application be reduced[.]”59

\footnotetext{
${ }^{56}$ CARl Schmitt, Political Theology: Four Chapters on the Concept of Sovereignty 1 (George Schwab trans., 1985) (1922); compare CARL SCHMITT, Die DikTATUR. VON DEN ANFÄNGEN DES MODERNEN SOUVERÄNITÄTSGEDANKENS BIS ZUM PROLETARISCHEN KLASSENKAMPF (1921). For an overview of these two works and their place in Schmitt's thought, see John P. McCormick, The Dilemmas of Dictatorship: Carl Schmitt and Constitutional Emergency Powers, in LAW AS POLITICS: CARL SCHMITT's CRITIQUE OF LIBERALISM 217 (David Dyzenhaus ed., 1998).

${ }^{57}$ See CARl SCHMITT, THE CRISIS OF PARLIAMENTARY DEMOCRACY (Ellen Kennedy trans., 1985); CARL Schmitt, Legality AND Legitimacy (Jeffrey Seitzer trans., 2004) (1932); William E. SCHEUeRmAn, BetweEn the Norm AND the EXCEPTION: THE FRANKFuRT SCHOOL AND THE Rule OF LAW (1994); William E. Scheuerman, The Economic State of Emergency, 21 CARDOZO L. REV. 1869 (2000).

${ }^{58}$ Scheuerman, supra note 57, at 1887 (emphasis omitted).

${ }^{59} I d$. at 1888.
} 
These points are abstract. We illustrate them by examining the role of Congress in the aftermath of 9/11 and the 2008 financial crisis. Our main claim will be that the Schmittian view supplies a better account of Congress' behavior in these crisis episodes than do competing views.

\section{Congress}

Madisonians describe Congress as the deliberative institution par excellence. On this view, Congress is a summation of local majorities, bringing local information and diverse perspectives to national issues. The bicameral structure of Congress aids deliberation; the House shifts rapidly in response to changing conditions and national moods, while the Senate provides a long-term perspective, and cools off overheated or panicky legislation.

It is unclear whether the Madisonian account is best taken to describe congressional action in normal times, in times of (perceived) crisis, or both, although the Madisonian emphasis on the cooling-off function of the Senate is clearly intended as a check on executive claims that an emergency is at hand. Whatever the case, the application of the Madisonian view to crises or emergencies is the default position among legal academics. On this view, even in crisis situations the executive may act only on the basis of clear congressional authorization that follows public deliberation, and the executive's actions must presumptively be subject to judicial review. A proviso to the Madisonian view is that if immediate action is literally necessary, the executive may act, but only until Congress can convene to deliberate; if the executive's interim actions were illegal, it must seek ratification from Congress and the public after the fact. ${ }^{60}$ In our view, by contrast, if we take current institutions as they are - thereby bracketing proposals for either large-scale constitutional reform ${ }^{61}$ or for small-scale, feasible improvements to Congress' design and procedures $^{62}$ - the Madisonian vision of Congress seems hopelessly optimistic in times of crisis.

On Schmitt's view, the deliberative aspirations of classical parliamentary democracy have become a transparent sham under modern conditions of party discipline,

\footnotetext{
${ }^{60}$ For a clear statement of this view, see Jules Lobel, Emergency Power and the Decline of Liberalism, 98 YALE L.J. 1385, 1424-40 (1989). See also Harold Koh, Why the President (Almost) Always Wins in Foreign Affairs: Lessons of the Iran-Contra Affair, 97 YALE L.J. 1255 (1988); John Hart Ely, Suppose Congress Wanted a War Powers Act that Worked, 88 CoLuM. L. REV. 1379 (1988). For more recent versions of this position, see David D. Cole, Judging the Next Emergency: Judicial Review and Individual Rights in Times of Crisis, 101 Mich. L. REv. 2565 (2003); Oren Gross, Chaos and Rules: Should Responses to Violent Crises Always Be Constitutional?, 112 Yale L. J. 1011 (2003). Some Madisonians put less emphasis on judicial review to ensure that the executive complies with constitutional norms, but insist on congressional involvement. See, e.g., Samuel Issacharoff \& Richard H. Pildes, Between Civil Libertarianism and Executive Unilateralism: An Institutional Process Approach to Rights During Wartime, 5 THEORETICAL INQ L. 1 (2004); Cass R. Sunstein, Minimalism at War, 2004 SuP. CT. REV. 47.

${ }^{61}$ Cf. Mark Tushnet, Controlling Executive Power in the War on Terrorism, 118 HARV. L. ReV. 2673 (2005); SANFORD LEVINSON, OUR UNDEMOCRATIC CONSTITUTION (2006).

${ }_{62}$ Adrian Vermeule, Mechanisms of Democracy: Institutional Design Writ Small (2007).
} 
interest-group conflict and a rapidly changing economic and technical environment. Rather than deliberate, legislators bargain, largely along partisan lines. Discussion on the legislative floor, if it even occurs, is carefully orchestrated posturing for public consumption, while the real work goes on behind closed doors, in party caucuses.

How does this picture relate to Schmitt's point that legislatures invariably "come too late" to a crisis? The basic dilemma, for legislatures, is that before a crisis they lack the motivation and information to provide for it in advance, while after the crisis has occurred, they have no capacity to manage it themselves. We will describe each horn of the dilemma in detail.

In the pre-crisis state, legislatures mired in partisan conflict about ordinary politics lack the motivation to address long-term problems. Legislation at this point would act from behind a veil of uncertainty about the future, and might thus prove relatively impartial; at least high uncertainty would obscure the distributive effects of the legislation for the future, and thus reduce partisan opposition. However, by virtue of these very facts, there is no strong partisan support for the legislation, and no bloc of legislators has powerful incentives to push it onto the crowded legislative agenda. The very impartiality that makes ex ante legislation relatively attractive, from a Madisonian perspective, also reduces the motivation to enact it.

This point is entirely independent of Schmitt's claim about the norm and the exception. In a modern rendition, that claim holds that ex ante legal rules cannot regulate crises in advance, because unanticipated events will invariably arise. Legislatures therefore either decline to regulate in advance or enact emergency statutes with vague standards that defy judicial enforcement ex post. ${ }^{63}$ Here, however, a different point is at issue: even if ex ante legal rules could perfectly anticipate all future events, legislatures will often lack the incentive to adopt them in advance. Occasionally, when a high-water mark of public outrage against the executive is reached, legislatures do adopt framework statutes that attempt to regulate executive behavior ex ante; several statutes of this kind were adopted after Watergate. The problem is that new presidents arrive, the political coalitions that produced the framework statute come apart as new issues emerge, and public outrage against executive abuses cools. Congress soon relapses into passivity and cannot sustain the will to enforce, ex post, the rules set out in the framework statutes. The post-Watergate framework statutes have thus, for the most part, proven to impose little constraint on executive action in crisis, in large part because Congress lacks the motivation to enforce them. ${ }^{64}$

\footnotetext{
${ }^{63}$ Lobel, supra note 60.

64 Andrew Rudalevige, The New Imperial Presidency: Renewing Presidential Power After Watergate (2005); Adrian Vermeule, Posner on Security and Liberty: Alliance to End Repression v. City of Chicago, 120 HARV. L. REV. 1251 (2007).
} 
The other horn of the dilemma arises after the crisis has begun to unfold. Because of their numerous memberships, elaborate procedures and internal structures, such as bicameralism and the committee system, legislatures can rarely act swiftly and decisively as events unfold. The very complexity and diversity that make legislatures the best deliberators, from a Madisonian perspective, also raise the opportunity costs of deliberation during crises and disable legislatures from decisively managing rapidly changing conditions. After 9/11, everyone realized that another attack might be imminent; only an immediate, massive response could forestall it. In September 2008, the financial markets needed immediate reassurance: only credible announcements from government agencies that they would provide massive liquidity could supply such reassurance. Indeed, though commentators unanimously urged Congress to take its time with the Paulson plan, ${ }^{65}$ within weeks the Bush administration was being criticized for not acting quickly enough. In such circumstances, legislatures are constrained to a reactive role, at most modifying the executive's response at the margins, but not themselves making basic policy choices.

The main implication of this dilemma is that crises in the administrative state tend to follow a similar pattern. In the first stage, there is an unanticipated event requiring immediate action. Executive and administrative officials will necessarily take responsibility for the front-line response; typically, when asked to cite their legal authority for doing so, they will either resort to vague claims of inherent power or will offer creative readings of old statutes. Because legislatures come too late to the scene, old statutes enacted in different circumstances, and for different reasons, are typically all that administrators have to work with in the initial stages of a crisis. "Over time, the size and complexity of the economy will outgrow the sophistication of static financial safety buffers" ${ }^{\prime}$ - a comment that can also be made about static security safety buffers, which the advance of weapons technology renders obsolete. In this sense, administrators also "come too late" - they are forced to "base decisions about the complex, ever-changing dynamics of contemporary economic [and, we add, security] conditions on legal relics from an oftentimes distant past." ${ }^{, 67}$

Thus Franklin Roosevelt regulated banks, in 1933, by offering a creative reading of the Trading with the Enemy Act of 1917, a statute that needless to say was enacted with different problems in mind. ${ }^{68}$ Likewise, when in 2008 it became apparent on short notice that the insurance giant AIG had to be bailed out, lest a systemwide meltdown occur, the Treasury and Federal Reserve had to proceed through a strained reading of a

\footnotetext{
${ }^{65}$ See, e.g., Letter from Professor Daron Acemoglu, et al., supra note 27.

${ }^{66}$ Robert F. Bruner \& Sean D. Carr, Lessons from the Financial Crisis of 1907, 19 J. ApPLIED CoRp. Fin. 115, 120 (2007).

${ }^{67}$ Scheuerman, supra note 57, at 1887.

${ }^{68}$ See Michel R. Belknap, The New Deal and the Emergency Powers Doctrine, 62 TEx. L. REV. 67, 71-73 (1983).
} 
hoary 1932 statute, as we discussed in Part I. While the statute authorized "loans," it did not authorize government to purchase private firms; administrators structured a transaction that in effect accomplished a purchase in the form of a loan. The pattern holds for security matters as well as economic issues, and for issues at the intersection of the two domains. Thus after 9/11, the Bush administration's attempts to choke off $\mathrm{Al}$ Qaeda's funding initially proceeded in part under provisions of the International Emergency Economic Powers Act, ${ }^{69}$ a 1977 statute whose purpose, when enacted, was actually to restrict the President's power to seize property in times of crisis. ${ }^{70}$

Crisis and delegation. ${ }^{71}$ In the second stage, Congress writes new statutes delegating broad powers to the executive to handle the crisis. It is simplistic to say, and we do not claim, that legislatures write the executive a blank check. On the other hand, it is equally false to say that during crises, Congress acts as a Madisonian deliberator, with institutions like bicameralism cooling of the heated passions of the public and of executive officials. The basic pattern is that the executive asks to take three steps forward; Congress, pushing back somewhat, has no choice but to allow it to take two. We will examine both parts of this pattern.

After the initial wave of strictly administrative response based on old statutes or vague claims of inherent authority, the executive asks Congress to delegate new powers. Executive proposals are typically sweeping, perhaps because the executive has private information about the magnitude of the crisis that it cannot fully convey to Congress, or because the executive uses the crisis as an opportunity to enlarge its power, or because the executive, anticipating a bargaining game with senior legislators, stakes out an extreme position - perhaps more extreme than the executive itself actually desires - so as to be well-positioned to make concessions.

Once the proposal is submitted to Congress, bargaining results, perhaps on a very compressed time-table. Large delegations are usually enacted quickly, and critics tend to complain of hasty or panicked lawmaking, although the critics often overlook the opportunity costs of deliberation, which rise in times of crisis. ${ }^{72}$ Here, suffice it to say that the speed of legislative enactment in such cases does not at all mean that the executive gets whatever it wants. What matters in (legislative) bargaining is not the parties' absolute haste, but their relative impatience. If the executive is even more impatient to enjoy the fruits of agreement than are legislators, or even more fearful of the consequences of nonagreement, then the executive will tend to make some concessions.

\footnotetext{
${ }^{69}$ Pub. L. No. 95-223, 91 Stat. 1626 (1977)

70 See Note, The International Emergency Economic Powers Act: A Congressional Attempt to Control Presidential Emergency Power, 96 HARV. L. REV. 1102 (1983).

${ }^{71}$ The following discussion draws on Adrian Vermeule, Emergency Lawmaking After 9/11 and 7/7, 75 U. CHI. L. REV. 1163 (2008).

${ }^{72}$ In the financial crisis of 2008, as in all crises, critics argue that the government is acting too quickly, while the government argues that it must act quickly. See, e.g., Bernanke Remarks on Stabilization, WALL ST. J., Oct. 15, 2008.
} 
Executives might be relatively more impatient than legislators because they need to show decisive leadership, because the public will hold them responsible for disasters, regardless of the legal situation, or because the political costs of bargaining failure are spread over many legislators, while executive officials each incur a large share of opprobrium.

All of these dynamics were on display in the bargaining over the AUMF, over the Patriot Act, and over the EESA. In the first case, the White House initially proposed a blank-check delegation to the President of power to respond as appropriate to "deter and preempt terrorism., ${ }^{, 3}$ The bargaining, although accomplished in a matter of days, ended up introducing a more restrictive nexus test, which limited the President's authority to the use of force against entities that had aided the 9/11 attacks. ${ }^{74}$ In the case of the Patriot Act, a rebellion by civil-libertarian Republican legislators in the House caused the administration to temporarily lose control of the bargaining process, resulting in a reduced grant of powers combined with a sunset provision. ${ }^{75}$

In the case of the EESA, the administration's initial plan was sketchy in the extreme, and would have granted legally unreviewable power to the Secretary of the Treasury to spend some $\$ 700$ billion dollars on the acquisition of mortgage-related assets, essentially without legislative standards. Rebellious House Republicans rejected one version of the bill, but the final legislation retained the core of the administration's proposal, while modifying it on several margins. The statute actually gave the Secretary additional new powers that the administration had not requested or perhaps even desired, such as the powers to buy an equity stake in distressed firms and to regulate executive pay. The former power would allow the Treasury to "nationalize" banks-that is, take them over and operate them. On the other hand, several oversight mechanisms were introduced, although as we will discuss shortly, their effectiveness is questionable. Finally, the legislation introduced some new substantive restrictions on the Secretary's new authority, and provided for staggered disbursement of the funds in a fashion reminiscent of the Patriot Act's sunset provisions.

In all these cases, the approximate result was the same. Measured either from the baseline of (1) what the executive initially requested or (2) what the executive actually desired (as best we can tell from indirect evidence), Congress pushed back substantially, despite the speed of legislative enactment; it narrowed proposed delegations or added delegations that the administration did not desire, added sunset provisions or similar mechanisms, and created oversight mechanisms. These points should not obscure,

\footnotetext{
${ }^{73}$ See David Abramowitz, The President, the Congress, and Use of Force: Legal and Political Considerations in Authorizing Use of Force Against International Terrorism, 43 HARV. INT'L L.J. 71, 73 (2002).

${ }^{74}$ Id. at $74-75$.

${ }^{75}$ See Beryl A. Howell, Seven Weeks: The Making of the USA PATRIOT Act, 72 GEO. WASH. L. ReV. 1145 (2004),
} 
however, that measured from the baseline of (3) the legal status quo ante the emergency, executives obtained broad new delegations of power. After the AUMF, the President possessed a great deal of statutory authority to combat terrorism, especially abroad; after the Patriot Act, that authority was extended to domestic criminal law and immigration matters; after the EESA, the President enjoyed broad statutory authority to rescue the economy from crisis.

The upshot is that in cases of emergency lawmaking, Congress lets the executive have most, although not all, of what it wants. Legislators have no real choice but to do so. In perceived crises, the status quo is unacceptable, but the costs and benefits of the alternatives to the status quo are highly uncertain; indeed the alternatives themselves are usually ill-defined. Congress' usual built-in advantage - inertia, or the ability of legislative leaders and interest groups to kill proposals at vetogates and thereby do nothing at all - is ruled out by politics. Congress can modify and push back to a degree, but the public, motivated by some mix of fear, urgency, and rational apprehension, demands that something be done.

In this situation, the executive has enormous inherent advantages. Where inaction is not an option, the executive's proposal is a natural focal point. The ability to move first by framing a proposal and putting it on the congressional agenda determines the contours of the subsequent bargaining game, even if Congress modifies the executive's proposal substantially. Legislators may be frustrated with the thrust of the executive's proposal, not merely the details, but be unable to find an alternative, or unable to force public attention onto their preferred alternative, out of the welter of suggestions and possibilities. Either where there are no alternatives or where there are too many, the executive's proposal will stand out.

Perhaps most of all, key legislators fear being stamped as obstructionists who have prevented the executive from taking necessary measures. The very nature of crisis bargaining implies that legislative leaders will become especially visible - there is no time for wide consultation of the rank-and-file - so the leaders' potential responsibility is heightened. Furthermore, legislative leaders can do something to focus public attention on back-benchers who threaten to scuttle a deal. In 2008, when the EESA came up for a second (and presumably final) vote in the House, leaders trumpeted to the public that everything depended on whether House Republican back-benchers would go along ${ }^{76}$ leaving the latter in the uncomfortable position of being the last obstacle to the emergency measures.

As we have mentioned, these effects are somewhat diluted because blame can be spread over a collective legislature, ensuring that individuals have reduced responsibility. Thus when the first version of the EESA was voted down in the House, one Republican

\footnotetext{
${ }^{76}$ See Greg Hitt \& Sarah Lueck, Senate Vote Gives Bailout Plan New Life --- Passage Gets Boost From Tax Breaks; Back to the House, WALl ST. J., Oct. 2, 2008, at A1.
} 
legislator remarked that the first choice of his colleagues was to have the bill pass while voting against it. ${ }^{77}$ The problem, as the event showed, was that because too many legislators acted on this preference, the bill did not pass at all. Ultimately, how these opposing forces working for and against broad delegation net out in particular cases of emergency lawmaking cannot be settled in the abstract, but only by looking at a series of cases. The pattern of recent history is clear enough: although legislators do push back against executive demands, in the end they accede to the core of the executive's proposals, both as to security matters and financial ones.

These causal claims about the politics of emergency lawmaking do not imply that legislators delegate "too much" power in crises. A hypothetical rational legislator, given emergency conditions, might delegate the same amount of power as an actual legislator buffeted by emotions and political winds. In Part III, we take up the question of the rationality of emergency delegations. Here, we merely note that political forces make large-scale delegation all but inevitable in such cases, although it is also true that the executive never gets all that it asks for or even all that it wants.

The irrelevance of divided government. How important is divided government in crisis bargaining over delegation? Whatever the importance of divided government in normal times, ${ }^{78}$ the partisan composition of Congress and the executive is of reduced importance in emergencies, or so the evidence suggests. In the bargaining over the Patriot Act, the administration lost control of Republican back-benchers in the House, who were concerned about civil liberties. In the bargaining over the EESA in September 2008, the administration lost control of Republican back-benchers in the House, who were concerned about "socialism" and the encroachment of government on the free market. In the first case, the Republicans held a majority, in the second they were in the minority. However, the second defection was as consequential as the first, because in 2008 the Democratic majority in the House was reluctant to enact the bill without the political cover provided by the support of the Republican minority. In effect, the minority party held a veto over the enactment; nominally divided government was effectively consensual government.

These two episodes illustrate several mechanisms that reduce the significance of divided government during emergency lawmaking. First, both the public and officialdom may experience emotions of genuine solidarity during a crisis, especially in its initial stages. A marker of such solidarity is that legislators transcend partisanship, at least temporarily. Second, even when the emotion of solidarity gets no purchase among hardened officials, public demand for bipartisanship in times of crisis can induce ersatz solidarity; fearing that the public will punish any actor who resorts to the open

\footnotetext{
${ }^{77}$ See Doyle McManus, Fear and Caution Ruled on the Hill; Voters Vented Fury at House Members Jittery About Their Jobs. Even Supporters Were Tepid., LA. Times, Sept. 30, 2008, at A1.

${ }^{78}$ See Daryl J. Levinson \& Richard H. Pildes, Separation of Parties, Not Powers, 119 HaRv. L. Rev. 2311 (2006).
} 
partisanship of normal times, legislators will grit their teeth and behave as though motivated by impartial concern for the public interest. Finally, emergencies often implicate new policy issues and unforeseen questions of institutional authority, both of which tend to cut across frozen partisan cleavages. In the case of the Patriot Act and the EESA, fears about civil liberties and economic liberties, or creeping "socialism," were both held by conservative Republicans in the House, while the Republican administration took an authoritarian stance on both security issues and economic issues. In those cases and also in the case of the September 2001 AUMF, there was evidence of bipartisan concern that an excessively broad delegation would overturn the allocation of lawmaking power among the branches. Although the latter concern was not sufficiently powerful to overcome the political forces favoring broad delegation, it did cause a degree of pushback against executive proposals.

Schmitt vs. Madison redux. The overall picture of Congress' role in emergency lawmaking, then, is as follows. Congress lacks motivation to act before the crisis, even if the crisis is in some sense predictable. Thus the initial administrative response will inevitably take place under old statutes of dubious relevance, or under vague emergency statutes that imposes guidelines that the executive ignores and that Congress lacks the political will to enforce, ${ }^{79}$ or under claims of inherent executive authority. After the crisis is underway, the executive seeks a massive new delegation of authority and almost always obtains some or most of what it seeks, although with modifications of form and of degree. When Congress enacts such delegations, it is reacting to the crisis rather than anticipating it, and the consequence of delegation is just that the executive once again chooses the bulk of new policies for managing the crisis, but with clear statutory authority for doing so.

In this pattern, Congress's structural incapacities ensure that, while Congress can shape and constrain the executive's response at the margins, it is fundamentally driven by events and by executive proposals for coping with those events, rather than seizing control of them. Schmitt's broad claim that the fast-moving conditions of the administrative state produce a marginal, reactive, and essentially debilitated Congress, whether or not true in normal times, is basically accurate during crises. At a minimum, it is closer to the mark than the Madisonian vision of a deliberative legislature that might rise to the occasion in times of crises, rather than handing power to the executive and hoping for the best.

The role of the Senate in the EESA's passage is particularly hard to square with the Madisonian view. Far from dampening hasty legislation with a calmly deliberative perspective, the Senate played two main roles. The first, a pluralist role, was to lubricate the bill's passage with pork-fat, such as a tax break for producers of wooden arrows (but

\footnotetext{
${ }^{79}$ See Lobel, supra note 60.
} 
not plastic ones) intended to gain the support of the Senators from Oregon. ${ }^{80}$ The Senate's second role was to put pressure on the House to act even more quickly and to approve the new delegation of executive authority. The Senate vote was accelerated by Senate leaders in order to approve the bill before the House's final vote, a move intended to underscore the obstructionism of House Republicans and to raise the political costs of their resistance. ${ }^{81}$ Rather than cooling off the sense of urgency behind the legislation, the Senate helped bring it to a boil.

To be sure, it is difficult to extract from the Madisonian view clear implications or predictions about how Congress will or should act during emergencies, in order to compare with the facts. Both the Schmittian view and the Madisonian view offer broad accounts of political processes and probabilistic tendencies, rather than point predictions. The Schmittian view, however, could clearly be falsified by imaginable outcomes. If Congress had rejected the bailout bill altogether, or decided to handle mortgage-related purchases itself, through its committees - and a great many detailed policy choices and appropriations matters were handled in exactly that way during the $19^{\text {th }}$ century - then the Schmittian view would have been falsified. If after 9/11 Congress had adopted a statute that restricted the president's power in future security emergencies, ${ }^{82}$ the Schmittian view would have been falsified in the security context. By the same token, however, if we are right that Congress played a marginal and reactive role during both crises, bucking against executive proposals but eventually giving in, griping from the stands, and reaching decisions mostly through bargaining rather than deliberation, it is fair to think that the Madisonian view does not capture the dynamics of crisis governance.

\section{The Courts}

As we have addressed the role of the courts in security emergencies at length elsewhere, ${ }^{83}$ and as courts have not yet made an appearance in the 2008 financial crisis, we will offer a briefer account here of their role in economic crises. In either context, courts are marginal participants. Here two Schmittian themes are relevant: that courts come too late to the crisis to make a real difference in many cases, and that courts have pragmatic and political incentives to defer to the executive, whatever the nominal standard of review. The largest problem, underlying these mechanisms, is that courts possess legal authority but not robust political legitimacy. Legality and legitimacy diverge in crisis conditions, and the divergence causes courts to assume a restrained role. We take up these points in turn.

\footnotetext{
${ }^{80}$ Michael Kranish \& Bryan Bender, A Wait To See If Tax Breaks Will Swing Bailout Vote, Boston GLOBE, Oct. 3, 2008, at A1.

${ }^{81}$ See Hitt \& Lueck, supra note 76, at A1 ("Senate leaders took up the bill, which had stronger support in that chamber, with the aim of putting pressure on the House.").

${ }^{82}$ Such as emergency statute proposed by Bruce Ackerman; see Bruce Ackerman, The Emergency Constitution, 113 YALE L.J. 1029 (2004).

${ }^{83}$ See POSNER \& VermeULe, supra note 2.
} 
The timing of review. A basic feature of judicial review in most Anglo-American legal systems is that courts rely upon the initiative of private parties to bring suits, which the courts then adjudicate as "cases and controversies" rather than as abstract legal questions. This means that there is always a time lag, of greater or lesser duration, between the adoption of controversial government measures and the issuance of judicial opinions on their legal validity. Common lawyers sometimes praise this delayed review precisely because the delay ensures that courts are less likely to set precedents while crises are hot, precedents that will be warped by the emotions of the day or by the political power of aroused majorities. ${ }^{84}$

Delayed review has severe costs, however. For one thing, courts often face a fait accompli. Although it is sometimes possible to strangle new programs in the crib, once those measures are up and running, it is all the more difficult for courts to order that they be abolished. This may be because new measures create new constituencies or otherwise entrench themselves, creating a ratchet effect, ${ }^{85}$ but the simpler hypothesis is just that officials and the public believe that the measures have worked well enough. Most simply, returning to the pre-emergency status quo by judicial order seems unthinkable; doing so would just re-create the conditions that led the legislature and executive to take emergency measures in the first place.

For another thing, even if courts could overturn or restrict emergency measures, by the time their review occurs, those measures will by their nature already have worked, or not. If they have worked, or at least if there is a widespread sense that the crisis has passed, then the legislators and public may not much care whether the courts invalidate the emergency measures after the fact. In the case of the EESA, one legal question we have discussed is whether the statute vests the Secretary of the Treasury with so much legal authority, without intelligible standards, as to violate the somewhat spectral "nondelegation doctrine." Although the legal claim is not intrinsically strong, the more important point is that by the time the courts issue a final pronouncement on the challenge, the program will either have increased liquidity and stabilized financial markets, or not. In either case, the nondelegation challenge will interest constitutional lawyers, but will lack practical significance.

Intensity of review. Another dimension of review is intensity rather than timing. At the level of constitutional law, the overall record is that courts tend to defer heavily to the executive in times of crisis, only reasserting themselves once the public sense of imminent threat has passed. ${ }^{86}$ At the level of administrative law, as to security matters,

\footnotetext{
${ }^{84}$ See Cole, supra note 60, at 2575-76; DAvid Dyzenhaus, The Constitution of LAw: Legality in A TiME OF EMERGENCY (2006). See also Korematsu v. United States, 323 U.S. 214, 242-48 (1944) (Jackson, J., concurring).

${ }^{85}$ For skepticism about these and related possibilities, see POSNER \& VERMEULE, supra note 2, at 131-56.

${ }^{86}$ Although we cannot document the assertion here, for a full treatment, see POSNER \& VERMEULE, supra note 2 .
} 
federal courts deciding cases after 9/11 have tended to defer in a range of important cases, ${ }^{87}$ although more large-number work is necessary to understand the precise contours of the phenomenon. Schmitt occasionally argued that the administrative state would actually increase the power of judges, insofar as liberal legislatures would attempt to compensate for broad delegations to the executive by creating broad rights of judicial review; ${ }^{88}$ consider the Administrative Procedure Act (APA), which postdates Schmitt's claim. It is entirely consistent with the broader tenor of Schmitt's thought, however, to observe that the very political forces that constrain legislatures to enact broad delegations in times of crisis also hamper judges, including judges applying APA-style review. While their nominal power of review may be vast, the judges cannot exercise it to the full in times of crisis.

Deference to executives in administrative-law cases can arise in two ways. In the first, administrative law creates a "black hole" in which there is no review at all. In the second, courts applying flexible standards of review, such as the "arbitrary and capricious" test that is a central feature of the APA, create a "grey hole." 89 In the latter case, despite the nominal availability of review, courts dial down the intensity of review in ways that are difficult for the Supreme Court or outside observers to check in particular cases, although the existence of the phenomenon will be quite obvious in the aggregate. $^{90}$

In the framing of the EESA, the same two modes of deference came into play. The Secretary's initial proposal would have excluded review altogether. The final version is best read to create standard APA-style review of the Secretary's actions, if only to avoid possible constitutional questions about nondelegation. Although, as we noted above, there is some ambiguity about what review the statute actually allows, we will indulge the assumptions least favorable to our view by stipulating that ordinary review is permitted.

The problem with APA-style review under the EESA, however, is that, as in other areas of administrative law, courts will predictably defer heavily to administrators' particular decisions in times of crisis. Courts do so both because they lack the information to second-guess those decisions in the complex circumstances of actual cases, and because they fear to be seen to thwart emergency measures. Lower courts, especially, are reluctant to challenge the decisions of the President and other high

\footnotetext{
${ }^{87}$ See Adrian Vermeule, Our Schmittian Administrative Law, 122 HARV. L. REV. (forthcoming 2009).

${ }^{88}$ Scheuerman, supra note 57 , at 1884-85.

${ }^{89}$ DyZenHAUS, supra note 84 , at 3.

${ }^{90}$ Cass Sunstein, Judging National Security (forthcoming), finds that in the aggregate judges deciding administrative law cases after 9/11 are highly deferential to the executive, and that although there are clear partisan differences in this regard, the differences are less pronounced than in other areas of judicial review of administrative action.
} 
executive officials in matters of national security; ${ }^{91}$ quite plausibly, the same will be true as to economic emergencies. And the questions at issue in such cases will generally be too numerous and too fact-bound for the Supreme Court to review more than a handful of them. ${ }^{92}$

Whether or not such deference is desirable in the abstract, the pragmatics of crisis governance give courts few alternatives. Consider the idea that courts could review the transactions the Secretary undertakes, in particular the prices he accepts at "reverse auctions" for mortgage-related securities. If courts subject these transactions to meaningful review, then sellers would be afraid that sales would be reversed, and the whole idea of the program - to encourage holders of assets to sell—would be undermined. If courts subject these transactions to highly deferential review, then review would serve little purpose. In any event, it is doubtful that courts could second-guess the Secretary's pricing decisions. The problem is that the mortgage-related asset market has collapsed, so there are no market prices to use as a benchmark. And given the likely complexity of these transactions, which would involve equity stakes, covenants of various sorts, and much else, courts would be in a difficult position if they sought to evaluate the transactions in a serious fashion.

In general, the Secretary's pricing decisions under the EESA are paradigmatic of the types of questions that courts find it difficult to review, involving as they do a combination of technicality, uncertainty about valuation, and urgency. The first two factors are also present in judicial review of rate regulation of public utilities by administrative agencies, which tends to be highly deferential; more broadly, the inability of courts to determine utility rates and common-carrier rates, through a succession of cases, was a major impetus behind the creation of early administrative agencies. ${ }^{93}$ Beyond the features common with other regulatory schemes in which uncertain valuation is a problem, the EESA carries with it an aura of urgency, which will make courts reluctant to be seen frustrating the only major statutory mechanism for coping with the financial crisis.

The upshot is that the EESA will, in all probability, create nothing more than a series of legal grey holes, rather than genuinely independent judicial oversight. Lawyers, who are frequently obsessed with the formal question whether judicial review is

\footnotetext{
${ }^{91}$ Sunstein makes this point for D.C. Circuit review of presidential decisions in security matters. See Cass R. Sunstein, National Security, Liberty, and the D.C. Circuit, 73 GEO. WASH. L. REV. 693 (2005).

${ }_{92}$ In the most recent comparable case- - the savings \& loan bailout of the 1980s-Congress established the Resolution Trust Corporation to take control of failed S\&L's and sell off their assets. Congress provided for greatly limited review (see 12 U.S.C. § 1821(j), which prohibited certain forms of injunctive relief)—no doubt because of skepticism about courts' ability to evaluate the RTC's sales decisions - and courts complied, even though there was no emergency or crisis. See, e.g., Ward v. Resolution Trust Corp., 996 F.2d 99 (5th Cir. 1993).

${ }^{93}$ See Stephen G. Breyer et Al., Administrative Law and Regulatory Policy 222-28 (6th ed. 2006).
} 
technically available or not, may draw comfort from Congress' decision to provide for arbitrariness review. From another perspective, however, legal grey holes may be worse than legal black ones. The former create an illusion of oversight, whereas the latter are in a sense more candid about whether meaningful review will in fact occur. ${ }^{94}$ Our perspective is that it is not useful to talk about whether black or grey holes are preferable. Some mix of both types is inevitable where statutes like the AUMF, Patriot Act and the EESA delegate administrative power to cope with an emergency. Background legalist statutes like the APA are themselves shot through with exceptions and qualifications that allow the standard pattern of crisis management to proceed without real check.

Legality and legitimacy. At a higher level of abstraction, the basic problem underlying judicial review of emergency measures is the divergence between the courts' legal powers and their political legitimacy in times of perceived crisis. As Schmitt pointed out, emergency measures can be "exceptional” in the sense that although illegal, or of dubious legality, they may nonetheless be politically legitimate, if they respond to the public's sense of the necessities of the situation..$^{95}$ Domesticating this point and applying it to the practical operation of the administrative state, courts reviewing emergency measures may be on strong legal ground, but will tend to lack the political legitimacy needed to invalidate emergency legislation or the executive's emergency regulations. Anticipating this, courts pull in their horns.

When the public sense of crisis passes, legality and legitimacy will once again pull in tandem; courts then have more freedom to invalidate emergency measures, but it is less important whether or not they do so, as the emergency measure will in large part have already worked, or not. The precedents set after the sense of crisis has passed may be calmer and more deliberative, and thus of higher epistemic quality - this is the claim of the common lawyers, which resembles an application of the Madisonian vision to the courts - but the public will not take much notice of those precedents, and they will have little sticking power when the next crisis rolls around.

\section{E. Other Oversight Mechanisms}

In emergency lawmaking, Congress routinely attaches strings to its delegations in the form of reporting provisions, sunset provisions, and a variety of other oversight mechanisms. Such provisions often amount to less than meet the eye. Reporting provisions - used in the AUMF, the Patriot Act, and the EESA - embody both a concern that Congress should be informed and also an elevated theory that transparency will promote democratic accountability. Yet in practice such provisions notoriously end up leveling forests to create massive documents that few people ever read.

\footnotetext{
${ }^{94}$ DyZENHAUS, supra note 84 , at 47.

95 See SCHMITT, LEGALITY AND LEGITIMACY, supra note 57.
} 
Both the Patriot Act and the EESA contain sunset provisions. ${ }^{96}$ The main theory of such provisions is that by creating a future reversion to the legal status quo ante the delegation, the sunset will make it easier to claw back new powers from the executive if a future Congress judges that the emergency has passed; the future Congress can do so simply by declining to re-enact the new powers, rather than having to affirmatively overturn them by a new statute, which could itself be vetoed. ${ }^{97}$ In practice, however, the difference between emergency statutes with and without sunsets is often small, for political reasons. When controversial provisions of the Patriot Act came up for renewal in 2005, the provisions were twice continued on a short-term basis while the administration played chicken with Democratic and Republican civil libertarians in the Senate, betting that legislators would not be willing to let the provisions lapse altogether. In the end, minor adjustments were made, but the bulk of the provisions were re-enacted, some permanently. $^{98}$

The EESA follows a broadly similar pattern to the Patriot Act by creating checking and monitoring mechanisms whose force is at best unclear. We will pass over the statute's reporting requirements and its sunset clause, to focus on two mechanisms of greater interest. The first involves periodic review by Congress itself, the second involves oversight by an independent board.

Congressional review. In the first mechanism, the EESA provides that the Secretary's last $\$ 350$ billion (!) in purchasing authority is subject to a “joint resolution” of disapproval. ${ }^{99}$ The theory of the provision is to secure review by a future Congress, akin to a sunset clause (which the EESA also contains). Yet this mechanism requires affirmative action by the future Congress, or at least a credible threat of such action; as such, it seems even less likely than a sunset clause to result in a real check on the executive. A joint resolution is just a statute by another name, so the disapproval would have to obtain a congressional supermajority in order to override a veto. The provision is not completely meaningless - for one thing, it waives complex internal legislative procedures and thus places the disapproval on a fast track - yet this does nothing to cure the basic problem. Similar statutes that require affirmative congressional action to check the executive, such as the National Emergencies Act, have tended to become dead letters. ${ }^{100}$ One may safely predict the same here.

Independent boards. The EESA also creates oversight by a putatively independent board, the "Financial Stability Oversight Board," which consists of the Secretary himself,

\footnotetext{
${ }^{96}$ EESA § 120.

${ }^{97}$ Jacob E. Gersen, Temporary Legislation, 74 U. CHI. L. REV. 247 (2007).

${ }^{98}$ See BRIAN T. YEH \& CHARLES DOYLE, USA PATRIOT IMPROVEMENT AND REAUTHORIZATION

ACT OF 2005: A LEgAL ANALYSIS (Cong. Research Serv., CRS Report for Congress Order Code RL33332, Dec. 21, 2006), available at http://www.fas.org/sgp/crs/intel/RL33332.pdf; see also Sheryl Gay Stolberg, Senate Passes Legislation To Renew Patriot Act, N.Y. Times, Mar. 3, 2006, at A14.

${ }^{99}$ EESA § 115(c).

${ }^{100}$ See Vermeule, supra note 64, at 1255.
} 
the Chairman of the Federal Reserve (Fed), the Chairman of the Securities and Exchange Commission (SEC), the Director of the Federal Housing Finance Agency (an independent commission recently created in other legislation), and the Secretary of Housing and Urban Development. ${ }^{101}$ Of these five, three are chairs or heads of "independent agencies," whose principals cannot be fired without cause, and this suffices to create a patina of independent oversight. In the case of the SEC, there is some degree of legal uncertainty about the independence of the commission, in part because the D.C. Circuit recently issued an expansive interpretation of the grounds for firing permitted by the statute. ${ }^{102}$ So one might describe the EESA as creating a Board consisting of two-and-ahalf independent agencies and two-and-a-half executive agencies -- another display of Congress' Solomonic wisdom.

However this may be, the aura of independence fades quickly when one considers the Board's powers and the actual conduct of its members. The Board is authorized to "review[] the exercise of [the Secretary's powers]," to ensure that the Secretary is carrying out the purposes and policies of the statute, to recommend action to the Secretary, and to send reports to appropriate congressional committees. ${ }^{103}$ These provisions are another exercise in "studied ambiguity."104 Their scope and force is vague, the crux of the ambiguity being whether the Board has power to actually countermand the Secretary's purchasing decisions and other orders, or whether its power to "review" simply amounts to a power to find out what the Secretary is up to and transmit information to Congress. The highminded interpretation is that Congress declined to give the Board clearly controlling authority because of lurking constitutional questions about whether the powers of a "core" executive agency like the Treasury could be subjected to independent control, even under the Court's latitudinarian precedents. ${ }^{105}$ The lowminded interpretation is that legislators benefitted politically by creating an oversight mechanism whose atmospherics suggest independent supervision of the Secretary's massive new powers, but whose operational reality is far less impressive.

Even if the Board had crystal-clear legal power to actually countermand the Secretary's decisions, a separate problem is whether the Board would in practice function as an autonomous check on the Secretary's extraordinary economic authority. The answer is likely to be no. Even before the EESA was enacted, the chair of the Fed, Ben Bernanke, acted hand in glove with the Treasury Secretary, Henry Paulson, with the latter in the role of lead partner. Part of the explanation here is that independent agencies face the same problems of legality and legitimacy that plague independent judiciaries in times

\footnotetext{
${ }^{101}$ EESA § 104.

${ }^{102}$ Free Enterprise Fund v. Pub. Co. Accounting Oversight Bd., 537 F.3d 667, 679-80 \& n. 8 (D.C. Cir. 2008).

${ }^{103}$ EESA § 104.

${ }^{104}$ Posting of Rick Pildes to Balkinization, supra note 50.

${ }^{105}$ Cf. Morrison v. Olson, 487 U.S. 654 (1988).
} 
of crisis. Lacking a direct channel of accountability to the President, they are partially insulated from politics, but are also vulnerable to criticism as "unelected bureaucrats.”

Moreover, recent empirical work suggests that the heads of independent agencies and executive agencies tend to have common preferences and beliefs, both aligned with those of the reigning President; at least this is especially likely to be so late in the second term of an eight-year Presidency. ${ }^{106}$ If this is correct, it is because the growing polarization of the political parties ensures that Presidents can reliably select and appoint independent agency heads whose preferences and views track their own. While a Senate dominated by the other party can slow down the rate of such appointments, and thus delay the time when Presidents take control of the independent agencies, eventually Presidents can do a great deal to coordinate all agency heads on common preferences and a common program, whatever their nominal legal status.

F. The Self-Fulfilling Crisis of Authority

Finally, we mention a dynamic that further tightens the political constraints in times of crisis. Precisely because markets expected the House to pass the EESA, its initial failure to do so created a perceived "crisis of authority,"107 suggesting a risk that dysfunctional political institutions would not be able to coordinate on any economic policy at all. That second-order crisis supervened on the underlying economic crisis, but acquired force independent of it. The Senate had to scramble to undo the damage and did so in world-record time. The House quickly fell into line.

In this way, measures urged by the executive to cope with a crisis of unclear magnitude acquired a kind of self-created momentum. Rejection of those measures would themselves create a political crisis that might, in turn, reduce confidence and thus trigger or exacerbate the underlying financial crisis. A similar process occurred in the debates over the AUMF and the Patriot Act, where proponents of the bills urged that their rejection would send terrorist groups a devastating signal about American political unity and will, thereby encouraging more attacks. These political dynamics, in short, create a self-fulfilling crisis of authority that puts legislative institutions under tremendous pressure to accede to executive demands, at least where a crisis is even plausibly alleged.

Critics of executive power contend that the executive exploits its focal role during crises in order to bully and manipulate Congress, defeating Madisonian deliberation when it is most needed. ${ }^{108}$ On an alternative account, the legislature rationally submits to executive leadership because a crisis can be addressed only by a leader. Enemies are emboldened by institutional conflict or a divided government; financial markets are

\footnotetext{
${ }^{106}$ Neal Devins \& David E. Lewis, Not-So Independent Agencies: Party Polarization and the Limits of Institutional Design, 88 B.U. L. REV. 459 (2008).

${ }^{107}$ David Brooks, Op-Ed., Revolt of the Nihilists, N.Y. TIMES, Sept. 30, 2008, at A27.

108 See, e.g., GeOfFrey StOne, Perilous Times: Free Speech in WARTime From The Sedition Act of 1798 TO THE WAR ON TERRORISM (2004); Cole, supra note 60, at 2591-92; Ackerman, supra note 82.
} 
spooked by it. ${ }^{109}$ A government riven by internal conflict will produce policy that varies as political coalitions rise and fall. Inconsistent policies can be exploited by enemies and they generate uncertainty at a time that financial markets are especially sensitive to agents' predictions of future government action. It is a peculiar feature of the 2008 financial crises that a damaged president could not fulfill the necessary leadership role, but that role quickly devolved to the Treasury Secretary and Fed Chair who, acting in tandem, have not once expressed disagreement publicly.

\section{$* * * * *$}

The basic similarity between the two episodes of emergency lawmaking, in 2001 and 2008, is somewhat obscured by the Sturm und Drang that accompanied the EESA's passage. Election-year politics exacerbated the political turmoil, but the Houses' initial rejection of the EESA resembled the revolt of civil-libertarian Republican back-benchers in the debate over the Patriot Act, just on a larger scale. Broadly speaking, the final result was strikingly similar: the executive got the core of its requested new power, with a few oversight mechanisms of uncertain force, including a remote future prospect of judicial review. Overall, the EESA, like the AUMF and the Patriot Act before it, exemplifies the usual outcome of Schmittian crisis management, albeit with some important contextual differences. We now turn to those differences.

\section{Variations in Crisis Governance}

The Schmittian view, even if correct, should not be understood to make point predictions about how any particular crisis will be resolved. Rather, it supplies a framework that helps to identify broad political constraints. What explains variations in crisis governance, within the constraints? In this Part, we both detail the differences between crisis governance in the two cases, and consider several explanations for those differences.

Critics of executive aggrandizement objected more loudly in 2001 than in 2008, but it is hard to measure the practical differences between the two cases. The executive's actions after 9/11 might seem more conspicuous and dramatic, but it is not clear that those actions-immigrant sweeps, profiling, detentions, even war-were more extreme than the government's intervention in financial markets, which involved the nearnationalization of a multi-trillion dollar industry. ${ }^{110}$ The main differences lie in law and rhetoric. After 9/11 the administration more clearly stretched or defied existing statutes-

\footnotetext{
109 See Milton Friedman \& AnNa Schwartz, A Monetary History of the United States, 18671960, at 418 (1963) ("The detailed story of every banking crisis in our history shows how much depends on the presence of one or more outstanding individuals willing to assume responsibility and leadership.”).

${ }^{110}$ In the Financial Crisis of 2008, the Fed, for the first time ever, placed hard-to-value, questionable assets on its balance sheet. See Posting of Paul Krugman to The Conscience of a Liberal, http://krugman.blogs.nytimes.com/2008/09/29/ok-we-are-a-banana-republic/ (Sept. 29, 2008, 15:02 EST); see also Posting of Paul Krugman to The Conscience of a Liberal, http://krugman.blogs.nytimes.com/2008/09/26/demolition-accomplished/ (Sept. 26, 2008, 9:57 EST).
} 
ignoring FISA and the anti-torture statute, for example-than it did during the financial crisis, and it made more aggressive arguments about its constitutional authority. In the 9/11 crisis, it invoked the commander-in-chief and vesting clauses of Article II of the Constitution; in the financial crisis, the Bush administration made no constitutional arguments.

We examine four explanations of these differences.

\section{A. The Madisonian View Revisited: Formal Law}

One possible explanation for these differences reverts back to the formal legal setting. On this theory, one set of legal rules governs security crises and another set of legal rules governs financial crises, and the security-crisis rules give the executive more authority to act unilaterally than the financial-crisis rules do. A variant of this theory is that there are special security-crisis rules but no financial-crisis rules: the executive's authority in financial crises is no greater than its authority during normal times. Where the Bush administration had adequate authority, it acted; where it did not, it sought the necessary authority.

This account cannot be the whole story. On the one hand, the Bush administration did stretch its statutory authorizations in both cases, perhaps violating some of them, so as to engage in actions that it thought necessary, although there was an important difference of degree. The NSA surveillance program and the administration's interrogation practices were in tension with statutes. The Fed's bailout of AIG was as well; the relevant statute authorized loans only, while the transaction was probably a purchase. On the other hand, the administration sought Congressional authorization, in both cases, for actions that it believed, or could have believed, were already lawful. The administration probably did not need the AUMF in order to launch an attack on Afghanistan, and it has never conceded that the statute was necessary. And the administration, acting through the Fed, could probably have bought up mortgage-related assets as necessary; it did not need statutory authorization to borrow, and could have borrowed hundreds of billions, even trillions, of dollars in order to buy those assets or the institutions that owned them.

In terms of formal written law, embodied in the Constitution and statutes, the difference between the two types of crises is small. The U.S. Constitution, unlike many foreign constitutions, has no explicit provisions for emergencies that give the executive heightened power. It does have a rule that grants Congress the authority to suspend habeas corpus during security crises only (rebellion or invasion), ${ }^{111}$ but Congress did not use that authority during the 9/11 crisis. A host of statutes address security and financial emergencies, but these statutes by definition embody Congressional authorization, so

${ }^{111}$ U.S. CONST. art. I, § 9, cl. 2. 
their existence cannot explain why the Bush administration stretched or violated statutes to a greater extent during the 9/11 crisis than during the financial crisis.

In terms of constitutional practice, the story is more complicated. In nearly every major war or security emergency since the founding, the executive has claimed broad powers to respond-in some cases violating statutes, in other cases violating constitutional rules that apply during normal times. ${ }^{112}$ Frequently noted examples include Lincoln's suspension of habeas corpus, Wilson's crackdown on wartime dissenters, and FDR's internment of Japanese-Americans. These and other precedents have given rise to a vigorous and controversial executive-branch jurisprudence of executive power that draws on the commander-and-chief and vesting clauses of the U.S. Constitution, and various judicial opinions that recognize the executive's primacy in foreign relations. ${ }^{113}$ The Bush administration drew on this traditional jurisprudence in the course of justifying its narrow interpretations of FISA and other statutes that stood in the way of its war-onterror tactics.

Precedent for emergency powers during financial crises is equally abundant. Consider FDR's first inaugural address in 1933, where he vaguely hinted that he might need dictatorial powers in order to address the Great Depression:

It is to be hoped that the normal balance of executive and legislative authority may be wholly adequate to meet the unprecedented task before us. But it may be that an unprecedented demand and need for undelayed action may call for temporary departure from that normal balance of public procedure.

I am prepared under my constitutional duty to recommend the measures that a stricken nation in the midst of a stricken world may require. These measures, or such other measures as the Congress may build out of its experience and wisdom, I shall seek, within my constitutional authority, to bring to speedy adoption.

But in the event that the Congress shall fail to take one of these two courses, and in the event that the national emergency is still critical, I shall not evade the clear course of duty that will then confront me. I shall ask the Congress for the one remaining instrument to meet the crisis-broad Executive power to wage a war against the emergency, as great as the power that would be given to me if we were in fact invaded by a foreign foe. ${ }^{114}$

FDR acknowledged that he would ask for, rather than seize, dictatorial powers. But the request would come only in the event that Congress failed to cooperate in the first place, leading one to wonder what might be the implied consequence if the request were turned down. And even if Congress were to grant FDR dictatorial powers, there would be no source for such a measure in the Constitution.

\footnotetext{
112 See POSNER \& VERMEULE, supra note 2.

113 See John Yoo, WAr by Other MeAns: An Insider's AcCOUnT OF THE WAR On TERror (2006).

114 Franklin D. Roosevelt, First Inaugural Address (Mar. 4, 1933), in 2 THE PUBLIC PAPERS AND ADDRESSES OF FRANKLIN D. ROOSEVELT 15 (1938).
} 
However one interprets FDR's address, Congress did cooperate with his legislative program, so his constitutional theory was never tested. In addition, the Great Depression in 1933 was far more serious than the financial crisis of 2008, which was more like 1929, when credit had frozen up but layoffs had not yet begun, than 1933, when a quarter of the workforce was unemployed, millions of people lived in shantytowns and roamed the roads, and there were sparks of revolutionary anger. No such conditions existed in 2008, so FDR's speech does not offer even a weak precedent. Therefore, the Bush administration had no basis for claiming unilateral emergency powers to address a financial crisis.

Differences in constitutional law and practice, then, might explain why the Bush administration acted more forcefully after 9/11 than during the financial crisis. A related point is that Congress had delegated broader authority to address financial crises than security crises. The Fed has enormous discretionary authority, as does Treasury, and the two institutions had used that authority to intervene in the credit market and rescue institutions long before the crisis of September 2008 occurred. By contrast, Congress had given the executive less explicit authority to counter military threats prior to 9/11. It had enacted a few emergency statutes with limited scope and it had acquiesced in much overseas military activity without attempting to regulate it. ${ }^{115}$ But it had imposed numerous constraints on law enforcement, intelligence, and military activities at home, where the threat posed by Al Qaida would become manifest. Thus, the Bush administration may have felt less need to claim constitutional sources of authority in the financial crisis than in the security crisis.

As noted above, however, the legal differences do not adequately explain the different approaches of the Bush administration to the two crises. It made aggressive statutory arguments in both crises, and it did go to some trouble to obtain legal authorization in the 9/11 crisis. A full explanation for the differences in approach must lie elsewhere.

\section{B. Magnitude and Nature of the Crisis}

Another explanation for the greater aggressiveness of the Bush administration after 9/11 than during the financial crisis is that the nature of the threat was different. On this view, the security crisis posed a threat to life and bodily integrity and to the economy, which depends on transportation and other facilities threatened by terrorists; the financial crisis posed a threat to prosperity and financial well-being. ${ }^{116}$ The security

\footnotetext{
115 See Lobel, supra note 60, at 1412-18.

116 For cost estimates with respect to 9/11, see, for example, Patrick Lenain et al., The Economic Consequences of Terrorism (Organization for Economic Cooperation and Development Working Paper No. 332, 2002); Andrew H. Chen \& Thomas F. Siems, The Effects of Terrorism on Global Capital Markets, 20 EuR. J. POL. ECON. 349 (2004); U.S. GOV’T ACCOUNTABILITY OFFICE, SEPTEMBER 11: RECENT ESTIMATES OF FISCAL IMPACT OF 2001 TERRORIST ATTACK ON NEW YORK (2005), available at www.gao.gov/new.items/d05269.pdf; GAIL MAKINEN, THE ECONOMIC EFFECTS OF 9/11: A RETROSPECTIVE
} 
crisis did not have any real precedent and shattered expectations about how the government can handle security threats; the financial crisis followed a long line of similar cyclical downturns. The security crisis required a response that would necessarily involve coercion and violence, including limitations on civil liberty; the financial crisis required a response that involved no more than shuffling money around. In sum, the stakes were higher after 9/11 than they were in 2008, and that explains why the Bush administration acted differently in the two crises.

This theory has a number of vulnerabilities. The relevant consideration is not whether the 9/11 attacks killed people or caused more economic harm than the failure of AIG and other firms in 2008; the relevant consideration is what these visible events tell us about the future. The 9/11 attacks implied further and possibly worse terrorist attacks in the future, including a nuclear attack, but no one could assign a probability to these worst-case events. The financial crisis implied further and possibly worse failures, with the worst case a Great-Depression style economic collapse. Both worst-case scenarios are major catastrophes; beyond that, little can be said about which set of events revealed a greater threat to people's well-being.

Moreover, while it is true that people have a visceral reaction to government actions that infringe on liberties, this point cuts against the claim that the Bush administration's more aggressive posture in the security crisis can be explained by reference to the nature of the crisis. In the view of the executive branch, the security crisis necessitated a government response that involved violence; the financial crisis necessitated a government response that did not involve violence. It was easy to anticipate that people would be more concerned about the violation of civil liberties than about increasing government debt. So the visceral reaction to infringement on liberties should have resulted in greater caution by the government after 9/11 rather than less, and hence greater eagerness to enlist Congress's help, compared to the financial crisis. Yet the opposite occurred.

Another theory is that the Bush administration needed Congress during the financial crisis because ultimately only Congress has the authority to appropriate funds to pay off the massive debts that the executive branch was incurred on behalf of the United States; without a signal of congressional support, creditors would fear that the debt might not be paid off, which would undermine the government's efforts to calm fears and reassure creditors. By contrast, military activity is the prerogative of the executive. However, Congress would ultimately have to pay the bills for the 9/11 response as well. In both cases, congressional support would strengthen the policies of the executive by making clear that those policies would survive short-term political turnover; for this reason, the executive rationally sought congressional support in both crises.

Assessment (Cong. Research Serv., CRS Report for Congress Order Code RL31617, Sept. 27, 2002), available at www.fas.org/irp/crs/RL31617.pdf. 
In sum, differences in the magnitude and nature of the crisis do not explain differences in the Bush administration's responses.

\section{The Psychology of Crisis}

A recurrent theme in discussions of crisis lawmaking is the role of fear. A standard account holds that during crises, public fear, or fear among legislators, causes those legislators to put their faith in the executive, and hence both to delegate power to it and to acquiesce when the executive claims new powers. ${ }^{117}$ Public fear during the 9/11 crisis accounts for the Bush administration's unilateralism at the time; by contrast, fear was muted during the financial crisis and hence the opportunity for exercising executive power was more limited.

To evaluate this argument, we must start with the idea of fear. Fear is sometimes used as a synonym for rational apprehension of a heightened threat, but in public debate fear usually refers to the tendency to overreact in response to a threat, compared to some baseline of rational action. ${ }^{118}$ Critics of the Bush administration believe that the public would have been better off with a less aggressive reaction to the terrorist attacks but supported the more aggressive action because of their fear.

Was there more fear after 9/11 than during the financial crisis? This question is virtually impossible to answer. Certainly, fear was widespread after 9/11, and many people stopped flying on airplanes, as a result. In the government, officials clearly felt fear as well. During the financial crisis, the general public was less fearful, although there was certainly a general level of anxiety. However, knowledgeable people-traders, executives, government officials-clearly felt fear. ${ }^{119}$ Indeed, the common phrase "financial panic" clearly signifies the role of fear in financial crises. A difference in the level of fear does not have much explanatory power.

Both crises generated another emotion-outrage and a thirst for vengeance. A crucial distinction is that during the 9/11 crisis, the outrage was directed (mostly) outward, to Al Qaida members and their supporters who lived mainly in foreign countries. During the financial crisis, the outrage was directed internally, at Wall Street financiers and government officials. As a result, the 9/11 crisis generated (temporary) political unity, while the financial crisis generated a populist backlash against the rich, and division between the country's elites and its public. It may be that the executive has a freer hand when public unity exists than otherwise. However, it is not clear why this should be so. If the public is unified, Congress should support the executive, in which case unilateralism become less necessary.

\footnotetext{
${ }^{117}$ Vermeule, supra note 71; POSNER \& VERMEULE, supra note 2, at 59-68.

118 For discussions, see Eric A. Posner, Law and the Emotions, 89 GEORGETOWN L.J. 1977, 2002-04 (2001); POSNER \& VERMEULE, supra note 2, at 59-68; Gross, supra note 60, at 1038-42.

${ }^{119}$ For one of countless descriptions of the sense of fear during the financial crisis, see Bryan Caplan, Panic Puzzle, Oct. 12, 2008, http://econlog.econlib.org//archives/2008/10/panic_puzzle.html.
} 
This brings us to our final point, which is the indeterminacy of theories based on fear and other emotions. ${ }^{120}$ A threat to security generates fear; but the fear could be directed at the external enemy, leading to a transfer of power to the executive, or the fear could be directed at the possibility of executive abuse of its powers, leading to imposition of limits on the executive, at least compared to the rational baseline. Similarly, a financial threat could lead to fear of economic collapse, or fear of abusive government action that exploits the crisis-leading to transfer of power to the executive if the first alternative is correct, and the imposition of limits on the executive if the second alternative is correct. Moreover, both effects could operate simultaneously, but in different directions, with unclear consequences overall.

Still, we can see some merit in the following conjecture. The 9/11 security threat generated fear of further attacks and outrage against an external threat, both of which led to greater confidence in the government and especially the executive branch, which traditionally has primary responsibility for repelling external threats. The financial crisis of 2008 generated fear of economic collapse, but also outrage directed both at wealthy elites and at the government that was supposed to regulate them. The distrust of the government and the division among Americans partly explains why the executive could not act as aggressively as it did after 9/11. We will develop this point in Section D.

\section{Credibility and Popularity of Government Officials}

Another theory is that the Bush administration could act more aggressively during the 9/11 crisis than during the financial crisis because it was more popular and had more credibility. People felt they could trust the administration with authority to engage in operations that would often be secret by necessity; secret behavior, or behavior that is based on hard-to-observe or hard-to-evaluate information, would also be necessary during the financial crisis but the administration could no longer be trusted. This theory rests on several important distinctions between the political and institutional context of the $9 / 11$ crisis and the financial crisis.

First, the Bush administration was more popular on 9/11 than it was in September, 2008. Bush's approval ratings ranged from 50 to 60 percent prior to $9 / 11$; they shot up into the 80 percent range after 9/11. By contrast, Bush's approval rating was in the 30 percent rage just prior to the financial crisis, and collapsed at its onset. ${ }^{121} \mathrm{~A}$ popular executive can bully Congress; an unpopular executive cannot.

Second, the Bush administration was more trusted on 9/11 than it was in September, 2008. In 9/11, the Bush administration was still an unknown quantity; it had whatever trust an untried presidency has, marred by the controversial 2000 election. In 2008, the Bush administration had lost a great deal of its credibility as a result of its false

\footnotetext{
${ }^{120}$ Vermeule, supra note 71, at 1169.

${ }^{121}$ President Bush: Job Ratings, http://www.pollingreport.com/BushJob1.htm (last visited Oct. 17, 2008).
} 
statements prior to the Iraq War and various political scandals. ${ }^{122}$ The Bush administration's efforts to enhance executive power by making broad legal claims about the basis of executive power in the Constitution backfired; whatever the merits of the legal claims, people feared executive aggrandizement, and Congress and the courts fought back by asserting their own institutional prerogatives. ${ }^{123}$ In late 2008, legal claims resting on inherent executive power would have fallen on deaf ears.

Third, on 9/11 Republicans controlled the House and almost half the Senate; they were in the ascendancy after a long period during which they had a subordinate position in a divided government. In September 2008, Democrats controlled both houses and the Republican brand had lost its luster. Although the 2008 Congress was extremely unpopular-even more unpopular than Congress in $2001^{124}$ —it also had greater confidence in itself and greater reason to oppose the Bush administration, which would accordingly need to act with greater care.

Finally, it was harder to blame Bush administration officials for 9/11 than for the financial crisis of 2008. On 9/11, Bush had been in office for less than one year, so much of the failure to prevent the crisis had to be attributed to his predecessor. In addition, the 9/11 attacks came out of the blue; it is not clear that they could have been foreseen and prevented. ${ }^{125}$ By contrast, in 2008, Bush administration officials had been in office for almost eight years. While the roots of the financial crisis can be found in decisions made in the 1990s, regulatory oversight since then was the responsibility of the Bush administration and it had failed.

However, there is an important countervailing consideration. So far, we have referred to the Bush administration as the main protagonist, and this is correct for the 9/11 crisis. But the financial crisis involved a more complex institutional response. The Fed is an independent agency and not directly under the control of the White House. In addition, it enjoys a very high level of confidence. The Fed's Chairman, Ben Bernanke, was highly regarded. Indeed, the reputation of the Fed prior to the crisis in 2008 was far more impressive than that of the Bush administration prior to 9/11.

\footnotetext{
${ }^{122}$ In July 2001, 60 percent of Americans viewed Bush as "honest and trustworthy”; by January 2007, that figure had dropped to 40 percent. See Washington Post-ABC News Poll, Jan. 16-19, 2007, http://www.washingtonpost.com/wp-srv/politics/polls/postpoll_012007.htm (last visited Oct. 17, 2008).

${ }^{123}$ For Congressional hearings on signing statements, see Presidential Signing Statements: Hearing Before the S. Comm. on the Judiciary, 109th Cong. (2006); Presidential Signing Statements under the Bush Administration: A Threat to Checks and Balances and the Rule of Law?: Hearing Before the H. Comm. on the Judiciary, 110th Cong. (2007); for judicial reaction, see, for example, Hamdan v. Rumsfeld, 548 U.S. 557 (2006) (finding that the administration did not have inherent authority to disregard Congressional limitations on military commissions).

${ }^{124}$ Mark Memmott \& Jill Lawrence, Gallup: Approval Rating for Congress Matches Lowest Ever Recorded, USA TODAY, Aug. 21, 2007, http://blogs.usatoday.com/onpolitics/2007/08/gallupapproval.html.

${ }^{125}$ The 9/11 report allocated blame liberally; our point is one of public perception. See NATIONAL COMMISSION ON TERRORIST ATTACKS UPON THE UNITED STATES, THE 9/11 COMMISSION REPORT (2004).
} 
Bernanke probably believed that the Fed did not have enough resources, legal authority, and political backing, to undertake the necessary response to the crisis by itself. It did not have enough assets, and it would need the Treasury's acquiescence in order to borrow more. Its legal authority was expansive but probably not sufficient, and by tradition it tried to limit itself to providing funds, rather than buying institutions or exotic securities. In any event, it would have to cooperate with other agencies such as Treasury, the SEC, and the FDIC, which had considerable authority over large parts of the financial system, and these institutions could be coordinated only through the executive branch. So the Bush administration's lack of credibility hampered the Fed as well.

Cutting against these points, the Bush administration had a Nixon-in-China advantage during the financial crisis of 2008 that it lacked in 2001. The lore has it that only Nixon, a hawkish, anti-communist Republican, could establish diplomatic relations with China because his conservative reputation rendered credible his claim that a relationship with China served the national interest; a Democrat would be suspected of being soft on national security. ${ }^{126}$ Generalizing, presidents can most assertively use their powers in a way that cuts against the grain of the president's ideological disposition. ${ }^{127}$ On this theory, Bush could not be trusted with military power because he was not known as a civil libertarian, but he could be trusted with economic power because no one thought he had any desire to nationalize the financial sector. As we have seen, however, events do not bear out this theory, perhaps because Bush did in fact expand the federal government during his two terms, and had already become known as a big-government Republican.

To sum up, the weakened position of the Bush administration may account for its less aggressive stance in the fall of 2008. The minimal public role of President Bush himself supports this thesis. But Congress did not take up the slack. Leadership was provided by a duumvirate consisting of Bernanke and Paulson, an awkward executive branch-independent agency alliance, which, however, acted as one.

\section{E. Voters and Cross-Border Effects}

We noted above that the 9/11 attacks generated outrage that was mostly directed toward foreigners, while the financial crisis generated outrage toward a subset of Americans. Here, we expand on this point, focusing not on the emotional valence of the response, but its political economy.

The response to the $9 / 11$ attacks would necessarily involve coercion by security personnel, whether law enforcement, immigration, or military. Such actions would infringe on, or threaten, rights to life, liberty, and bodily integrity. However, the victims of these actions would mostly be foreigners. Although the administration claimed the

\footnotetext{
${ }^{126}$ Alex Cukierman \& Mariano Tommasi, When Does It Take a Nixon to Go to China?, 88 Am. ECON. Rev. 180 (1998).

${ }^{127}$ Robert E. Goodin, Voting Through the Looking Glass, 77 AM. PoL. SCI. REv. 420 (1983).
} 
right to detain and kill Americans who belong to Al Qaida as well, this claim raised hackles and was rarely acted upon.

By contrast, the response to the financial crisis would mainly take the form of taking money from some Americans (taxpayers) and giving it to other Americans (those with interests in institutions that own mortgage backed securities and related assets). In the best case, taxpayers would gain more than they lose, but the best case was hardly certain. Thus, actions taken to resolve the financial crisis would necessarily create divisions among Americans. This may be why the Paulson bill, AUMF-like in its simplicity, never stood a chance. The Dodd Bill and then the Senate bill that was passed had hundreds more pages that ensured that the constituents of members of Congress were paid off with dozens of transfers that were remotely or not at all related to the financial crisis.

If the most plausible response to the 9/11 attacks would benefit Americans generally, by enhancing security, and come at the expense of non-Americans, then it may well have been rational for Americans to disregard traditional political checks on the executive. Under the circumstances, it was less likely than usual for the executive to use its enhanced powers against political opponents. By contrast, many if not most Americans believed that any government response to the financial crisis would involve redistributing wealth, and so they looked to Congress to defend their interests.

This story is appealing and may have elements of the truth. However, every government action is redistributive; the 9/11 response had different effects on Muslim Americans and on other Americans. It had different effects on people who lived in cities and on those who did not, and on people who traveled on airplanes and on those who did not. Complaints would soon arise that the newly created Department of Homeland Security issued grants on a political basis. A powerful executive has as many opportunities to make transfers among voters during security emergencies as during financial crises. Accordingly, potential American victims of executive overreach existed in both crises, and these Americans would resist executive aggrandizement in both crises.

Still, as a matter of public perception, the 9/11 response seemed more like a traditional military response against an external enemy that had struck a blow against the United States and posed a threat to everyone at home, while the response to the financial crisis was not directed against an external enemy, but instead seemed to benefit foreign and American financial elites who had harmed ordinary Americans and now stood to gain from those same Americans' expense. ${ }^{128}$ In the latter set of circumstances, the executive

\footnotetext{
${ }^{128}$ The Paulson plan initially included foreign banks in its provisions, and a brief populist backlash against policies that helped foreigners arose. See Mark Landler, Financial Chill May Hit Developing Countries, N.Y. Times, Sept. 26, 2008, at C9 ("Treasury Secretary Henry M. Paulson Jr. has resisted efforts by Congress to make foreign banks ineligible for the plan.”); Nelson D. Schwartz \& Carter Dougherty, Foreign Banks Hope An American Bailout Will Be Global, N.Y. TIMES, Sept. 22, 2008, at C1.
} 
would need to work harder to reassure Americans that it acted in their interests, and enlisting Congressional support was an essential aspect of this effort.

\section{Conclusion}

From our comparison of the two crises, we draw two conclusions. First, both crises support the Schmittian view over the Madisonian view. Congress can neither anticipate crises with statutory structures that provide the executive with properly limited authority to address the threat, nor legislate after the crisis in a fashion that appropriately regulates the executive. Beforehand, legislatures lack the information and motivation needed to provide for the crisis in advance. After the crisis begins, legislatures lack time, information, and the institutional mechanisms that are necessary for useful deliberation. They can only provide broad support to the executive. If they do not, they can only make the crisis worse. Rational legislators hold their noses and delegate power even when they do not trust the executive and disagree with its ideological disposition or announced policies. The broad delegations use vague standards that frustrate judicial review ex post.

Second, the executive will nonetheless have an interest in enlisting congressional support. Congressional support can enhance the credibility of the executive's policies. ${ }^{129}$ The Bush administration cooperated more with Congress during the 2008 financial crisis than during the 2001 security crisis because the administration's credibility had eroded in the meantime and the public's reaction to the financial crisis, which could be blamed on some Americans, was more divided than its reaction to the terrorist attacks. Congress acquiesced in both instances, giving the administration what it wanted but extracting mostly unrelated transfers in return.

We have examined only two crises and it is dangerous to generalize. However, the pattern of congressional and judicial deference to the executive during wartime emergencies has been extensively studied and confirmed. ${ }^{130}$ A thorough study of financial crises must await future work, but a few comments are appropriate here.

In the twentieth century, there have been numerous financial crises ${ }^{131}$ but two stand out for their magnitude: the bank panic of 1907, when the stock market fell by 37 percent, and the Great Depression of the 1930s. The 1907 bank panic was distinguished by the absence of government leadership: the executive had no power to regulate banks; Congress did not act either. Into this vacuum stepped J.P. Morgan, the leading investment banker of the time, who arranged for a private consortium to inject liquidity into the

\footnotetext{
${ }^{129}$ See Eric A. Posner \& Adrian Vermeule, The Credible Executive, 74 U. CHI. L. ReV. 865 (2007).

${ }^{130}$ See Posner \& Vermeule, supra note 2; William H. Rehnquist, All the Laws But One: Civil Liberties in WARTIME (1998); Clinton ROSSITER, CONSTITUTIONAL Dictatorship: CRIsis GOVERNMENT IN THE MODERn DEMOCRACIES (1948).

${ }^{131}$ See Frederic S. Mishkin \& Eugene N. White, U.S. Stock Market Crashes and Their Aftermath: Implications for Monetary Policy, in Asset Price BubBles 53, 55 (William C. Hunter \& George G. Kaufman eds., 2003) (counting 15 stock market crashes). There have been other crises, including currency runs and the collapse of financial institutions.
} 
banking system and stave off collapse. The lesson was not that private citizens could be relied on or that next time Congress would speedily provide needed authority, but that weak administrative institutions were unacceptable. Policymakers instituted a series of reforms that led to the Federal Reserve System, which was given broad discretionary authority to respond to financial crises. ${ }^{132}$

This turned out to be insufficient. The Fed dithered in response to the crash of 1929, and confidence was not restored until Roosevelt came to office, declared a bank holiday, and compelled Congress to pass the Emergency Banking Act. (It took Congress eight hours to pass this bill.) ${ }^{133}$ Although New Deal economic policies may have exacerbated the Great Depression, Roosevelt's charismatic leadership helped restore confidence in the financial system and ensured that economic collapse did not result in political strife as it did in so many other countries. New Deal legislation delegated unprecedented power to the executive, and Roosevelt used it aggressively to maintain order at home, despite an economic and political crisis that lasted a decade. ${ }^{134}$ The pattern of a strong executive with primacy during financial crises was established, and it has lasted to this day. It is the normal mode of crisis governance in the administrative state.

Readers with comments should address them to:

Professor Eric A. Posner

University of Chicago Law School

1111 East 60th Street

Chicago, IL 60637

eric_posner@law.uchicago.edu

\footnotetext{
${ }^{132}$ For accounts, see Bruner \& Carr, supra note 66; Jon R. Moen \& Ellis W. Tallman, Why Didn't the United States Establish a Central Bank until after the Panic of 1907? (1999) (unpublished manuscript); ROBERT F. BRUNER \& SEAN D. CARR, THE PANIC OF 1907 (2007).

${ }^{133}$ See ARTHUR M. SCHLESINGER JR., THE COMING OF THE NEW DEAL 7-10 (2003).

${ }^{134}$ ARTHUR M. SCHLESINGER JR., THE IMPERIAL PRESIDENCy (1973).
} 


\section{Chicago Working Papers in Law and Economics (Second Series)}

For a listing of papers 1-399 please go to Working Papers at http://www.law.uchicago.edu/Lawecon/index.html

400. Shyam Balganesh, Foreseeability and Copyright Incentives (April 2008)

401. Cass R. Sunstein and Reid Hastie, Four Failures of Deliberating Groups (April 2008)

402. M. Todd Henderson, Justin Wolfers and Eric Zitzewitz, Predicting Crime (April 2008)

403. Richard A. Epstein, Bell Atlantic v. Twombly: How Motions to Dismiss Become (Disguised) Summary Judgments (April 2008)

404. William M. Landes and Richard A. Posner, Rational Judicial Behavior: A Statistical Study (April 2008)

405. Stephen J. Choi, Mitu Gulati, and Eric A. Posner, Which States Have the Best (and Worst) High Courts? (May 2008)

406. Richard H. McAdams and Janice Nadler, Coordinating in the Shadow of the Law: Two Contextualized Tests of the Focal Point Theory of Legal Compliance (May 2008, revised October 2008)

407. Cass R. Sunstein, Two Conceptions of Irreversible Environmental Harm (Mary 2008)

408. Richard A. Epstein, Public Use in a Post-Kelo World (June 2008)

409. Jonathan R. Nash, The Uneasy Case for Transjurisdictional Adjudication (June 2008)

410. Adam B. Cox and Thomas J. Miles, Documenting Discrimination? (June 2008)

411. M. Todd Henderson, Alan D. Jagolinzer, and Karl A. Muller, III, Scienter Disclosure (June 2008)

412. Jonathan R. Nash, Taxes and the Success of Non-Tax Market-Based Environmental Regulatory Regimes (July 2008)

413. Thomas J. Miles and Cass R. Sunstein, Depoliticizing Administrative Law (June 2008)

414. Randal C. Picker, Competition and Privacy in Web 2.0 and the Cloud (June 2008)

415. Omri Ben-Shahar, The Myth of the “Opportunity to Read” in Contract Law (July 2008)

416. Omri Ben-Shahar, A Bargaining Power Theory of Gap-Filling (July 2008)

417. Omri Ben-Shahar, How to Repair Unconscionable Contracts (July 2008)

418. Richard A. Epstein and David A. Hyman, Controlling the Costs of Medical Care: A Dose of Deregulation (July 2008)

419. Eric A. Posner, Erga Omnes Norms, Institutionalization, and Constitutionalism in International Law (August 2008)

420. Thomas J. Miles and Eric A. Posner, Which States Enter into Treaties, and Why? (August 2008)

421. Cass R. Sunstein, Trimming (August 2008)

422. Cass R. Sunstein, Second Amendment Minimalism: Heller as Griswold (August 2008)

423. Richard A. Epstein, The Disintegration of Intellectual Property (August 2008)

424. John Bronsteen, Christopher Buccafusco, and Jonathan Masur, Happiness and Punishment (August 2008)

425. Adam B. Cox and Thomas J. Miles, Judicial Ideology and the Transformation of Voting Rights Jurisprudence (August 2008)

426. Daniel Abebe and Jonathan S. Masur, A Nation Divided: Eastern China, Western China, and the Problems of Global Warming (August 2008)

427. William Birdthistle and M. Todd Henderson, One Hat Too Many? Investment Desegregation in Private Equity (August 2008)

428. Irina D. Manta, Privatizing Trademarks (abstract only) (September 2008)

429. Paul J. Heald, Testing the Over- and Under-Exploitation Hypothesis: Bestselling Musical Compositions (1913-32) and Their Use in Cinema (1968-2007) (September 2008)

430. M. Todd Henderson and Richard A. Epstein, Introduction to “The Going Private Phenomenon: Causes and Implications” (September 2008)

431. Paul Heald, Optimal Remedies for Patent Infringement: A Transactional Model (September 2008)

432. $\quad$ Cass R. Sunstein, Beyond Judicial Minimalism (September 2008)

433. Bernard E. Harcourt, Neoliberal Penality: The Birth of Natural Order, the Illusion of Free Markets (September 2008) 
434. Bernard E. Harcourt, Abolition in the U.S.A. by 2050: On Political Capital and Ordinary Acts of Resistance (September 2008)

435. Robert Cooter and Ariel Porat, Liability for Lapses: First or Second Order Negligence? (October 2008)

436. Ariel Porat, A Comparative Fault in Defense Contract Law (October 2008)

437. Richard H. McAdams, Beyond the Prisoners' Dilemma: Coordination, Game Theory and the Law (October 2008)

438. Dhammika Dharamapala, Nuno Garoupa, and Richard H. McAdams, Belief in a Just World, Blaming the Victim, and Hate Crime Satatutes (October 2008)

439. M. Todd Henderson, The Impotence of Delaware's Taxes: A Short Response to Professor Barzuza's Delaware's Compensation (October 2008)

440. Richard McAdams and Thomas Ulen, Behavioral Criminal Law and Economics (November 2008)

441. Cass R. Sunstein, Judging National Security post-9/11: An Empirical Investigation (November 2008)

442. Eric A. Posner and Adrian Vermuele, Crisis Governance in the Administrative State: 9/11 and the Financial Meltdown of 2008 (November 2008) 